\title{
Cationic Pd(II)-catalyzed C-H activation/cross-coupling reactions at room temperature: synthetic and mechanistic studies
}

\author{
Takashi Nishikata, Alexander R. Abela, Shenlin Huang and Bruce H. Lipshutz
}

\author{
Full Research Paper \\ Address: \\ Department of Chemistry \& Biochemistry, University of California, \\ Santa Barbara, CA 93106, USA \\ Email: \\ Bruce H. Lipshutz - lipshutz@chem.ucsb.edu \\ * Corresponding author \\ Keywords: \\ arylation; cationic palladium; C-H functionalization; green chemistry; \\ olefination
}

\author{
Beilstein J. Org. Chem. 2016, 12, 1040-1064. \\ doi:10.3762/bjoc. 12.99 \\ Received: 18 January 2016 \\ Accepted: 28 April 2016 \\ Published: 20 May 2016 \\ This article is part of the Thematic Series "C-H \\ Functionalization/activation in organic synthesis". \\ Guest Editor: R. Sarpong
}

(C) 2016 Nishikata et al; licensee Beilstein-Institut.

License and terms: see end of document.

\begin{abstract}
Cationic palladium(II) complexes have been found to be highly reactive towards aromatic $\mathrm{C}-\mathrm{H}$ activation of arylureas at room temperature. A commercially available catalyst $\left[\mathrm{Pd}(\mathrm{MeCN})_{4}\right]\left(\mathrm{BF}_{4}\right)_{2}$ or a nitrile-free cationic palladium(II) complex generated in situ from the reaction of $\mathrm{Pd}(\mathrm{OAc})_{2}$ and $\mathrm{HBF}_{4}$, effectively catalyzes $\mathrm{C}-\mathrm{H}$ activation/cross-coupling reactions between aryl iodides, arylboronic acids and acrylates under milder conditions than those previously reported. The nature of the directing group was found to be critical for achieving room temperature conditions, with the urea moiety the most effective in promoting facile coupling reactions at an ortho $\mathrm{C}-\mathrm{H}$ position. This methodology has been utilized in a streamlined and efficient synthesis of boscalid, an agent produced on the kiloton scale annually and used to control a range of plant pathogens in broadacre and horticultural crops. Mechanistic investigations led to a proposed catalytic cycle involving three steps: (1) $\mathrm{C}-\mathrm{H}$ activation to generate a cationic palladacycle; (2) reaction of the cationic palladacycle with an aryl iodide, arylboronic acid or acrylate, and (3) regeneration of the active cationic palladium catalyst. The reaction between a cationic palladium(II) complex and arylurea allowed the formation and isolation of the corresponding palladacycle intermediate, characterized by X-ray analysis. Roles of various additives in the stepwise process have also been studied.
\end{abstract}

\section{Introduction}

Transition metal-catalyzed, direct functionalization of aryl C-H bonds has made enormous progress over the past decade, and continues to attract a great deal of attention due to the highly efficient routes now available for elaborating aromatic rings.
While reactions of this type have been known for decades [1-71], serious challenges remain in achieving reactivity and selectivity due to the inertness and ubiquity of $\mathrm{C}-\mathrm{H}$ bonds. High temperatures are frequently required to realize aromatic $\mathrm{C}-\mathrm{H}$ 
functionalization $\left(>120^{\circ} \mathrm{C}\right)$, increasing the potential for side reactions and functional group compatibility issues. Indeed, $\mathrm{C}-\mathrm{H}$ activation transformations until recently have rarely proceeded at ambient temperature due to the typically low reactivity of these positions [72-79]. In the case of palladium-catalyzed $\mathrm{C}-\mathrm{H}$ activation, the crucial, namesake " $\mathrm{C}-\mathrm{H}$ activation" step typically involves a $\mathrm{C}-\mathrm{H}$ to $\mathrm{C}-\mathrm{Pd}$ refunctionalization, generating a reactive aryl-palladium species that is poised for further transformations.

Three approaches (Figure 1) have generally been employed to enhance the reactivity and promote the key metalation/C-H bond cleavage step: (1) tuning of the reaction conditions through inclusion of various additives such as metal salts [1-22], or strong acids such as TFA or HOAc, in addition to the application of heat, although it is not always clear which steps within the overall mechanism are most directly effected under these conditions; (2) in a major subset of $\mathrm{C}-\mathrm{H}$ activation chemistry, internally chelating ortho-directing groups [71-85] have been found to effectively promote selective $\mathrm{C}-\mathrm{H}$ activation, typically by aiding in the formation of a palladacycle intermediate. Careful tuning of the structure of the directing group, with functionalities including a variety of nitrogen-containing moieties, such as amides [86,87], $N$-heterocycles [88,89], imines [90,91], pyridine $N$-oxide [92], amines [93,94], as well as a variety of others [1-71], has been found to profoundly impact reactivity; (3) tuning of ligands around the transition metal catalyst center has emerged as an especially powerful means of enhancing and controlling reactivity in these processes [95-107].
A fourth approach with considerable potential, and which appears to have received considerably less attention, involves tuning the cationicity of the transition metal catalyst [72-79]. Literature studies have suggested that certain anionic ligands on palladium, such as acetate or carbonate, may assist $\mathrm{C}-\mathrm{H}$ bond cleavage by acting as internal bases as part of a concerted metalation-deprotonation (CMD) pathway, particularly in the case of less electron-rich arenes (Scheme 1, top) [34,108-119]. In other arrays, particularly those with more electron-rich substituents, evidence suggests an electrophilic aromatic substitution mechanism may be operative. In these instances, electron-poor catalysts, such as those generated from the reaction of Pd(II) and TFA, have in some cases been shown to be especially effective. We reasoned that substitution with a more distant coordinating anion would result in a highly Lewis acidic, dicationic palladium species that might be still more reactive in the electrophilic palladation step, potentially gaining entry to $\mathrm{C}-\mathrm{H}$ activation under even milder reaction conditions for selected couplings than have previously been observed (Scheme 1, bottom) [120-122].

Metal cations, in general, are well known to increase the reactivity of $\mathrm{C}-\mathrm{C}$ and $\mathrm{C}-\mathrm{N}$ double bonds due to their Lewis acidity. Cationic palladium complexes [123], in particular, possess a wide breadth of reactivity, having been used to catalyze Diels-Alder [124,125], aldol and Mannich reactions [126-128], Wacker oxidations [129], polymerizations of alkenes [130,131], and asymmetric 1,4-additions with arylboronic [132-134], arylbismuth [135], and arylsilicon [136] reagents. Although carbocations react with arenes through electrophilic aromatic hydro-

(1) Tuning general conditions

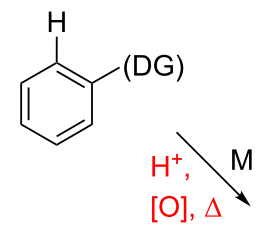

(2) Tuning directing group

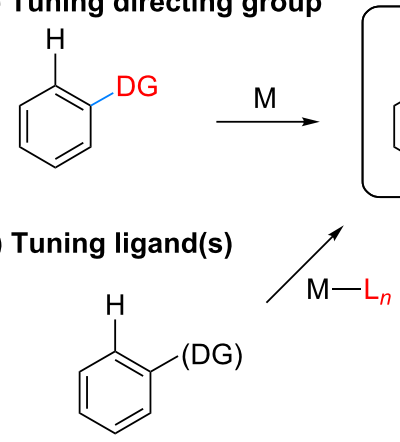

(4) Tuning catalyst cationicity

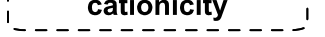

$\mathrm{M}^{n+}$<smiles>Oc1ccccc1O</smiles>

$D G=$ directing group

$M=$ catalyst 


\section{Concerted metalation-deprotonation (CMD)}

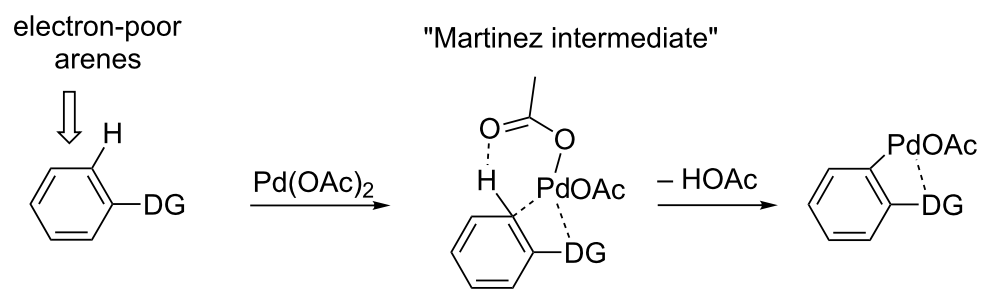

\section{Electrophilic palladation}

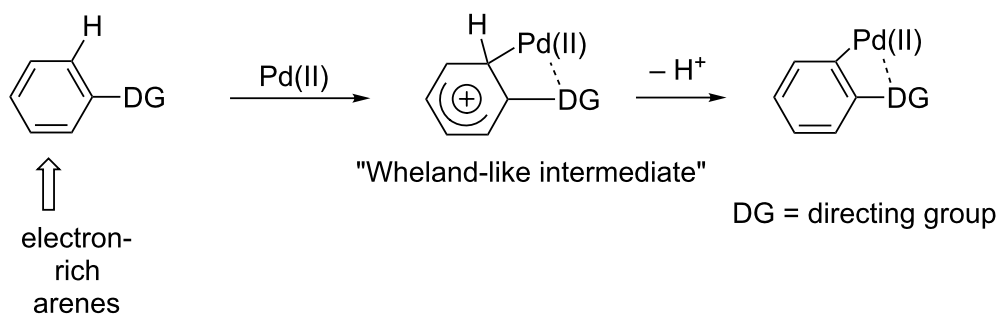

Scheme 1: Concerted metalation-deprotonation and elelectrophilic palladation pathways for $\mathrm{C}-\mathrm{H}$ activation.

gen substitution in a Friedel-Crafts reaction, the potential for metal cations to participate in similar chemistry has been far less widely examined. A cationic palladium-catalyzed electrophilic aromatic $\mathrm{C}-\mathrm{H}$ substitution without basic anions [137142] would hold considerable promise as an alternative and potentially milder approach to achieving valued $\mathrm{C}-\mathrm{H}$ activation/ coupling reactions.

While several cationic palladium complexes are commercially available, they may also be generated in situ via a variety of routes (Scheme 2), including: (a) reaction of a palladium complex with a non-coordinating anion source, usually an acid or metal salt; (b) reaction of $\mathrm{Pd}(\mathrm{II})$ halide complexes and silver salts [143-145]; (c) electronic oxidation of $\operatorname{Pd}(0)$ [146]; and (d) chemical oxidation of $\mathrm{Pd}(0)$ with $\mathrm{HBF}_{4}, \mathrm{Cu}\left(\mathrm{BF}_{4}\right)_{2}$ or $\mathrm{AgBF}_{4}$ $[136,147,148]$.

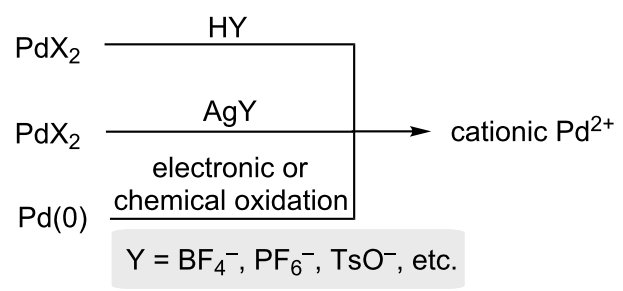

Scheme 2: Routes for generation of cationic palladium(II) species.

We have previously reported that cationic palladium-catalyzed C-H arylations of arylureas $[121,122]$ and Fujiwara-Moritani reactions of anilide derivatives [148] can be effected at room temperature. In this account we disclose, in addition to full details associated with this $\mathrm{C}-\mathrm{H}$ activation chemistry, additional applications of room temperature Fujiwara-Moritani reactions including a synthesis of the herbicide boscalid, as well as spectroscopic and mechanistic studies.

\section{Results and Discussion $\mathrm{C}-\mathrm{H}$ arylations of arylureas with aryl iodides and arylboronic acids}

Among the most conceptually attractive approaches to aromatic $\mathrm{C}-\mathrm{H}$ activation is the efficient synthesis of biaryls through direct arylation reactions. The widespread availability of aryl iodides and arylboronic acids make them appealing arylating agents [149-171]. Previously reported C-H activation reaction conditions employing these reagents, however, have typically required high temperatures to obtain the desired coupling products in good yields. In order to successfully carry out these reactions at ambient temperature, several considerations must be addressed, as illustrated in Figure 1. Optimization studies initially focused on the choice of an ortho-directing group together with a cationic palladium(II) catalyst. Although the combination of acetanilide together with a palladium(II) catalyst lead to the corresponding palladacycle, as reported by Tremont [172], in the presence of $\mathbf{2 a}, \mathrm{Pd}(\mathrm{OAc})_{2}, \mathrm{HBF}_{4}$ and $\mathrm{AgOAc}$ at room temperature, acetyl or isopropyl anilides afford essentially no product. Only after heating to $50{ }^{\circ} \mathrm{C}$ did substrate 1a react with iodide $\mathbf{2 a}$. The corresponding pivaloylanilide is also known to serve as an effective directing group at $130{ }^{\circ} \mathrm{C}$, but at room temperature a poor yield was obtained. Only the dimethylurea analog gave satisfactory conversion to the desired biaryl, thus arriving at optimized conditions, as shown in Scheme 3 (left). By contrast, the Daugulis group and others 

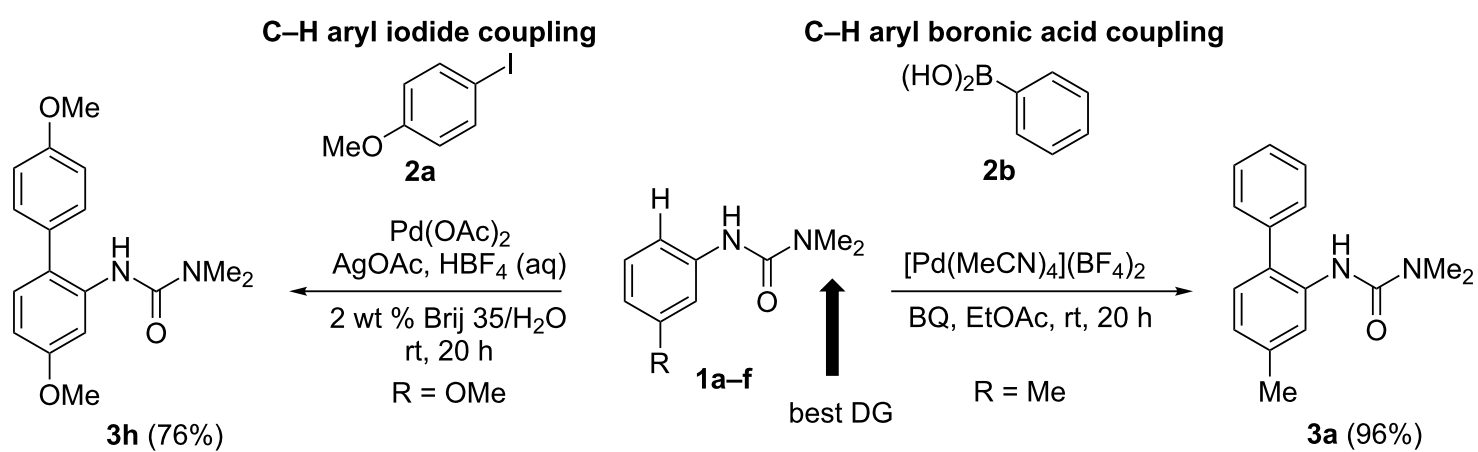

[other surfactants screened: PTS, Triton X-100, solutol] [other solvents screened: THF, DMF, EtOH, acetone]

Scheme 3: Optimized conditions for $\mathrm{C}-\mathrm{H}$ arylations at room temperature.

$[173,174]$ have demonstrated Pd-catalyzed ortho-arylations of anilides at temperatures typically greater than $100{ }^{\circ} \mathrm{C}$, and the Sanford group has also studied similar transformations involving diaryliodonium salts [175]. Arylureas have recently been noticed to be more active coupling partners for $\mathrm{C}-\mathrm{H}$ functionalizations as opposed to anilides, especially at lower temperatures [176]. A number of strong acids have been previously utilized in $\mathrm{C}-\mathrm{H}$ activation reactions [1-22], e.g., $\mathrm{HBF}_{4}$ was found to be critical for generation of biaryl $\mathbf{3 h}$ in good yield. The structure of the ortho-arylated product was confirmed by $\mathrm{X}$-ray analysis. While similar reactions, in addition to requiring high temperatures, have typically employed strong acids such as TFA as the organic solvent, here $2 \mathrm{wt} \%$ solutions of selected surfactants in water were found to be excellent reaction media, providing an additional environmentally appealing feature to this protocol. While good yields could be obtained using the first generation surfactant PTS (polyoxyethanyl $\alpha$-tocopheryl sebacate) $[121,177,178]$, several other amphiphiles that are both less costly and are items of commerce gave comparable results. Using commercialy available Brij 35 (2 wt \%) in water [179183] afforded the best levels of conversion and thus, overall yields, while in its absence (i.e.,"on water"), there was a noticeable drop in the extent of conversion. In addition, lower loadings of $\mathrm{HBF}_{4}$, silver salt, or the palladium catalyst also gave inferior results.

In the case of $\mathrm{C}-\mathrm{H}$ activation/Suzuki-Miyaura coupling reactions, the commercially available, pre-formed cationic $\mathrm{Pd}(\mathrm{II})$ catalyst $\left[\mathrm{Pd}(\mathrm{MeCN})_{4}\right]\left(\mathrm{BF}_{4}\right)_{2}[184]$, was found to efficiently catalyze the reaction between arylureas and arylboronic acids. On the other hand, $\mathrm{C}-\mathrm{H}$ arylations with aryl iodides catalyzed by $\left[\mathrm{Pd}(\mathrm{MeCN})_{4}\right]\left(\mathrm{BF}_{4}\right)_{2}$ did not give any of the desired products (see mechanistic discussion; vide infra). Various neutral palladium catalysts were examined, such as $\mathrm{Pd}(\mathrm{OAc})_{2}, \mathrm{PdCl}_{2} \mathrm{~L}_{n}$, $\mathrm{Pd}_{2}(\mathrm{dba})_{3}$, in the absence of added acid, but none led to cross- coupling at room temperature. 1,4-Benzoquinone (BQ) was found to be an effective additive in promoting the reaction, while addition of stoichiometric metal salts (e.g., silver or copper salts) was unnecessary. Moreover, in this case organic solvents were far more effective as the reaction medium than was water, possibly due to BQ solubility issues. EtOAc, rather than EtOH and THF was the most effective (Scheme 3, right), while other organic solvents (e.g., DMF) gave low-to-moderate yields of product 3a. Although reduced amounts of both phenylboronic acid (2b) and BQ still gave excellent yields, lower catalyst loadings caused slower reactions. A neutral palladium(II) complex, $\mathrm{Pd}(\mathrm{OAc})_{2}$, showed no catalytic acitivity, whereas catalytic $\mathrm{Pd}(\mathrm{OAc})_{2}$ in the presence of stoichiometric $\mathrm{HBF}_{4}$ reacted with an arylurea and arylboronic acid to afford the biaryl in high yield (Scheme 4).

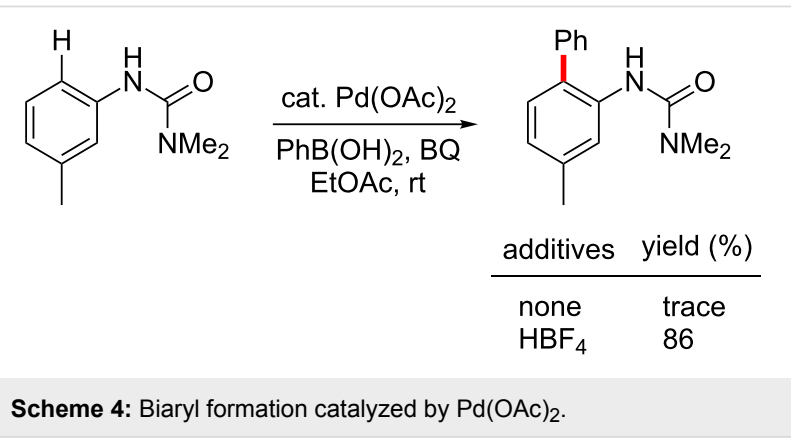

Representative results for the reactions between aryl iodides and arylboronic acids are summarized in Figure 2. These arylations tolerate various combinations of substrates and reagents having electron-withdrawing or electron-donating groups, as well as sterically hindered aromatic rings, all taking place at room temperature. Suzuki-Miyaura-type $\mathrm{C}-\mathrm{H}$ coupling reactions are typically more tolerant of electron-withdrawing groups (3d, 3f, 3k) and ortho-substitution (3g) on the aryl ring. On the other hand, 


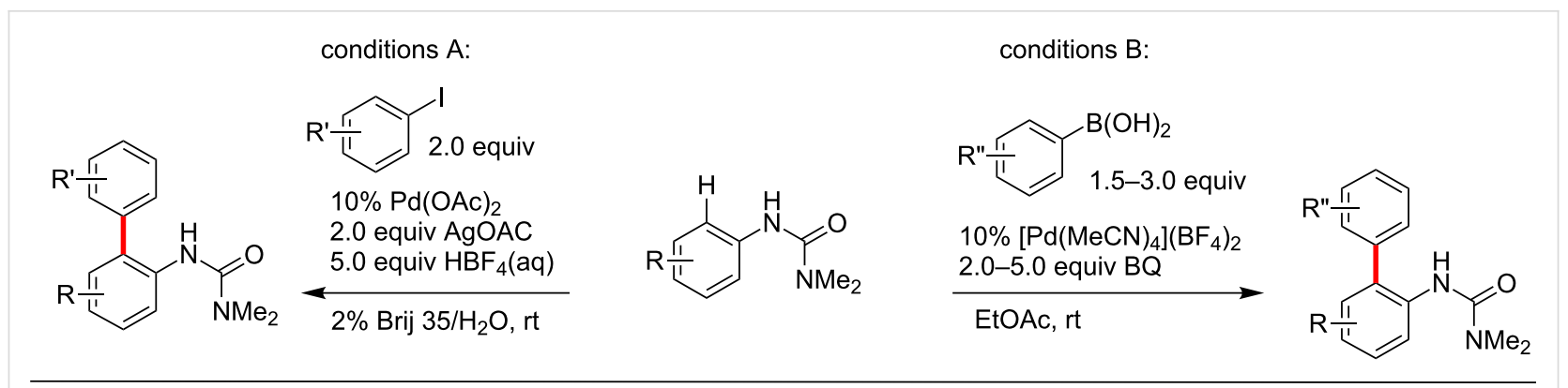

products: yield (conditions)<smiles>COc1ccc(-c2ccc(C)cc2NC(=O)NCC(C)(C)C)cc1</smiles><smiles>CCCCCCCNC(=O)Nc1cc(C)ccc1-c1ccc(C)cc1</smiles>

$74 \%$ (A) $90 \%(B)$<smiles>CC(=O)Nc1cc(C)ccc1-c1ccc(C(C)=O)cc1</smiles>

3d:

$75 \%$ (B)<smiles>CCCCCCCNC(=O)Nc1cc(OC)ccc1-c1ccc(C)cc1</smiles>

$$
87 \%(A)
$$

$87 \%(B)^{b}$<smiles>COc1ccc(-c2ccc(OC)cc2NC(=O)NC(C)([18OH])[18OH])cc1</smiles>

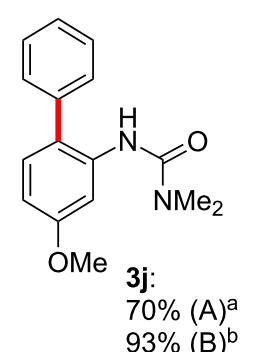<smiles>Cc1ccc(-c2ccc(C(C)(F)F)cc2)c(NC(=O)OCc2ccccc2)c1</smiles>

$86 \%(B)^{a}$

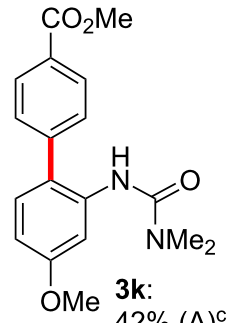
$42 \%(A)^{c}$ $70 \%$ (B)<smiles>Cc1ccc(-c2ccc(Cl)cc2)c(NC(=O)NCc2ccccc2)c1</smiles>

$94 \%(B)^{a}$<smiles>COc1ccc(OC)c(-c2ccc(C)cc2NC(=O)OCC(C)(C)C)c1</smiles>

3g: $98 \%$ (B)<smiles>COc1cc(NC(C)=O)c(-c2ccc(C)cc2)cc1Cl</smiles><smiles>CNC(=O)Nc1cc(OCc2ccccc2)ccc1-c1ccc(C)cc1</smiles><smiles>CC(=O)Nc1cc(C)c(C)cc1-c1ccccc1</smiles><smiles>Cc1ccc(-c2ccc(Cc3ccccc3)cc2NC(=O)NC(C)(Br)C(C)(C)C)cc1</smiles><smiles>CC(=O)Nc1cc(C(C)C)ccc1-c1ccc(C)cc1</smiles><smiles>CCCNC(=O)Nc1c(C)cccc1-c1ccc(C)cc1</smiles>

3t:

$72 \%(A)^{d}$ $65 \%(B)^{a}$<smiles>COc1cc(NC(C)=O)c(-c2ccc(C)cc2)cc1C</smiles><smiles>CN(C)C(=O)N1CCc2cccc(-c3ccccc3)c21</smiles>

3v: $90 \%(B)^{a}$<smiles>Cc1ccc(-c2cccc3c2N(C(=O)N(C)C)CC3)cc1</smiles>

3w: $89 \%(B)^{a}$<smiles>CNC(=O)Nc1cc(C(C)(C)C)ccc1-c1ccc(C)cc1</smiles>

Figure 2: $\mathrm{C}-\mathrm{H}$ arylation results. Conditions $\mathrm{A}$ : Conducted at $\mathrm{rt}$ for $20 \mathrm{~h}$ in $2 \mathrm{wt} \% \mathrm{Brij} 35 /$ water $(1 \mathrm{~mL})$ with $10 \mathrm{~mol} \% \mathrm{Pd}(\mathrm{OAc})_{2}$, AgOAc (2 equiv), $\mathrm{HBF}_{4}$ (5 equiv), arylurea (1, $\left.0.25 \mathrm{mmol}\right)$, and Arl (2.0 equiv). Conditions B: Conducted at rt for $20 \mathrm{~h}$ in EtOAc (1 mL) with $10 \mathrm{~mol} \%$

$\left[\mathrm{Pd}(\mathrm{MeCN})_{4}\right]\left(\mathrm{BF}_{4}\right)_{2}, \mathrm{BQ}$ (2 or 5 equiv), arylurea $(1,0.25 \mathrm{mmol})$, and $\mathrm{ArB}(\mathrm{OH})_{2}\left(1.5\right.$ or 3 equiv). ${ }^{\text {aRun }}$ for $48 \mathrm{~h}$. ${ }^{\mathrm{b}} 2$ equiv of $\mathrm{BQ}$. ${ }^{\mathrm{R}} \mathrm{Run}$ for $96 \mathrm{~h}$. ${ }^{\mathrm{d}} \mathrm{Run}$ for $72 \mathrm{~h}$. 
the reaction with 4-methoxycarbonylphenyl iodide, for example, gave a low yield of product 3k. Arylureas having only an electron-withdrawing group showed no reactivity towards coupling under either set of conditions (3x), consistent with an electrophilic aromatic substitution pathway in the initial $\mathrm{C}-\mathrm{H}$ activation step by a cationic palladium(II) species (vide infra). Arylureas with various alkyl substituents in the ortho-position, including cyclic arrays, gave good isolated yields $(\mathbf{3 t}, \mathbf{3 v}, \mathbf{3 w})$, whereas a 2-phenyl substituted arylurea did not participate in the $\mathrm{C}-\mathrm{H}$ activation/coupling reaction under these conditions (3y). Overall, C-H Suzuki-Miyaura coupling reactions were applicable to a broader substrate scope than the corresponding reaction with aryl iodides, although the latter protocol remains appealing for a variety of cross-coupling combinations due to both the convenience of aryl iodides as substrates, and the use of water as the gross reaction medium.

Especially noteworthy are the numerous examples of aniline derivatives lacking ortho- or meta-substitution, which have previously been shown to be prone to double arylation (Figure 3). Since literature conditions generally employ elevated temperatures, directed $\mathrm{C}-\mathrm{H}$ arylations have often suffered from uncon- trollable double arylation in symmetrical or unsubstituted substrates [1-22,173,174]. At ambient temperatures, however, coupling reactions on these more challenging substrate types underwent selective mono-arylations in water (Figure 3). In fact, doubly arylated products were rather difficult to generate under these room temperature conditions, not unexpected given the previously described low reactivity of ureas already possessing an ortho-aryl substituent [121,122].

A 1-naphthylurea also gave excellent selectivity at room temperature (Scheme 5). When this substrate was subjected to optimized conditions for the boronic acid $\mathrm{C}-\mathrm{H}$ coupling, the corresponding singly ortho-arylated product was obtained in $97 \%$ yield solely as the 2 -aryl isomer, as confirmed by ${ }^{1} \mathrm{H}$ NMR and X-ray crystallography. Generally, it is difficult to efficiently control the selectivity between the $\mathrm{C} 2$ and $\mathrm{C} 8$ positions in naphthalene rings towards a single isomeric $\mathrm{C}-\mathrm{H}$ activation product [163,174,185-189].

\section{Fujiwara-Moritani reactions}

Following these results on biaryl constructions via $\mathrm{C}-\mathrm{H}$ activation at room temperature, we next sought to apply our cationic<smiles>CCCNC(=O)Nc1ccc(OC)cc1-c1ccc(C)cc1</smiles>

3aa:

$72 \%(100: 0)(A)^{a}$ $82 \%(100: 0)(B)^{b}$

3bb: $89 \%(100: 0)(B)^{b}$<smiles>CCCCNC(=O)Nc1ccccc1-c1ccc(OC)cc1</smiles>

3ff: $75 \%(>20: 1)(A)^{d}$<smiles>CCC(C)c1ccc(NC(=O)N(C)C)c(-c2ccc(OC)cc2)c1</smiles>

3cc: $71 \%(>20: 1)(A)$<smiles>CCNC(=O)Nc1ccccc1-c1ccc(C)cc1</smiles>

3gg:

$70 \%(>20: 1)(A)^{d}$ $78 \%(>20: 1)(B)^{b}$<smiles>CCC(C)c1ccc(NC(=O)Nc2ccc(C(C)CC)cc2-c2ccc(C)cc2)c(-c2ccccc2)c1</smiles><smiles>CN(C)C(=O)Nc1ccccc1-c1ccccc1</smiles>

3hh:

$83 \%(>20: 1)(B)$

Figure 3: Monoarylations in water at rt. Conditions A: Conducted at rt for $20 \mathrm{~h}$ in 2 wt \% Brij 35/water with $10 \mathrm{~mol} \% \mathrm{Pd}(\mathrm{OAc})_{2}, \mathrm{AgOAc}(2 \mathrm{equiv})$, $\mathrm{HBF}_{4}\left(5\right.$ equiv), arylurea $(1,0.25 \mathrm{mmol})$, and $\mathrm{Arl}\left(\mathbf{2}, 1.5\right.$ equiv). Conditions B: Conducted at rt for $20 \mathrm{~h}$ in $\mathrm{EtOAc} \mathrm{with} 10 \mathrm{~mol} \%\left[\mathrm{Pd}(\mathrm{MeCN})_{4}\right]\left(\mathrm{BF}_{4}\right)_{2}$, $\mathrm{BQ}$ (5 equiv), arylurea $(1,0.25 \mathrm{mmol})$, and $\mathrm{ArB}(\mathrm{OH})_{2}\left(2,1.5\right.$ equiv). The ratios of single:double arylation determined by ${ }^{1} \mathrm{H} N \mathrm{NR}$ are shown in the parentheses. ${ }^{a}$ Run for $48 \mathrm{~h}$. ${ }^{\mathrm{b}} 1.2$ equiv of $\operatorname{ArB}(\mathrm{OH})_{2} .{ }^{\mathrm{c}} 1.2$ equiv of Arl. dRun for $72 \mathrm{~h}$. 


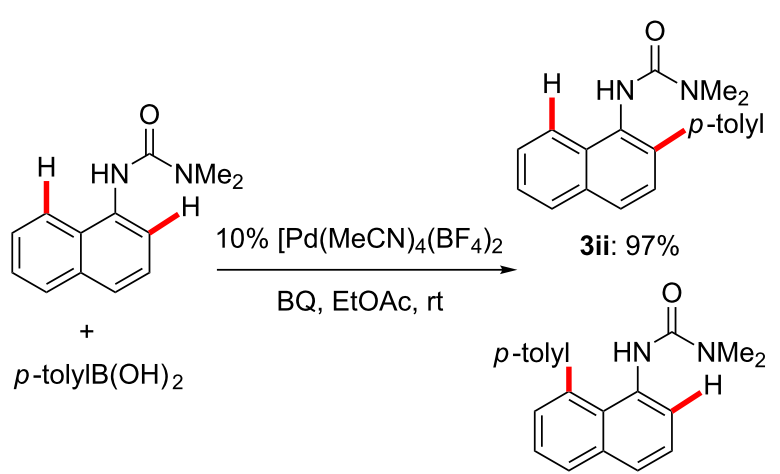

$3 \mathrm{jj}: 0 \%$

Scheme 5: Selective arylation of a 1-naphthylurea derivative.

palladium(II) conditions to the venerable Fujiwara-Moritani reaction. As reported back in 1967, this direct aryl olefination reaction is among the first palladium-catalyzed $\mathrm{C}-\mathrm{H}$ activation reactions to be described [190-192]. Subsequent studies have

generally resorted to elevated temperatures $\left(80-160^{\circ} \mathrm{C}\right)$ and anhydrous conditions, and in many cases high pressures of $\mathrm{CO}$ or $\mathrm{O}_{2}$ are also required in order to carry out these Heck-like coupling reactions [1-22,193-203]. Additional progress of note includes coupling reactions with arenes containing an orthodirecting group [1-22,45-51,193-203], as well as a meta-selective Fujiwara-Moritani reaction [204,205]. A recent report employing arylureas as the $\mathrm{C}-\mathrm{H}$ coupling partner achieved limited coupling at ambient temperature, with most examples requiring heating to $60{ }^{\circ} \mathrm{C}[74,206]$.

We have previously reported a methodology enabling Fujiwara-Moritani reactions to be run in water at room temperature using the cationic palladium catalyst $\left[\mathrm{Pd}(\mathrm{MeCN})_{4}\right]\left(\mathrm{BF}_{4}\right)_{2}$ (Figure 4, 5a-c, conditions A). While this reaction proceeded with a number of alkyl anilide derivatives, as well as ureas as directing groups $(\mathbf{5 c})$, the substrate scope was otherwise somewhat limited; only anilides possessing a strongly donating alkoxy group meta to the directing group (para to the position<smiles>[R]C(=O)C=Cc1ccc([R])cc1NC(=O)NC(C)=O</smiles><smiles>CCCCC(CC)COC(=O)/C=C/c1ccc(OC)cc1NC(=O)N(C)C</smiles>

5a: $74 \%(A)$<smiles>CCC(CC)COC(=O)/C=C/c1ccc(C)cc1NC(=O)N(C)C</smiles>

5d: $86 \%$ (B)<smiles>COC(=O)Nc1cc(OC)ccc1/C=C/C(=O)Nc1ccccc1</smiles>

5g: $83 \%(B)$

product/yield (conditions)<smiles>CCCCCCC(C)OC(=O)/C=C/c1ccc(OC)cc1NC(=O)N(C)C</smiles>

5b: $76 \%(A)$<smiles>COc1ccc(/C=C/C(=O)OCc2ccccc2)c(NC(=O)O[Na])c1</smiles>

5e: $99 \%(B)$<smiles>CCOC(=O)C(Cc1ccccc1)NC(=O)/C=C/c1ccc(OC)cc1NC(C)=O</smiles>

5h: $69 \%(B)$

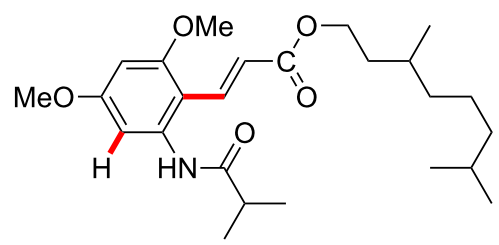

5c: $80 \%(A)$<smiles>COc1cc(NC(=O)N(C)C)c(/C=C/C(C)=O)cc1C</smiles>

5f: $89 \%(B)$ 
where the $\mathrm{C}-\mathrm{H}$ activation would occur) were reactive. However, we have since found that use of acetonitrile-free, in situ generated cationic palladium with arylureas as the directing group expanded the substrate scope to include reactions with 3-alkyl-substituted ureas, as well as a wider variety of acrylates and even some acrylamides (Figure 4, $\mathbf{5 d}-\mathbf{h}$, conditions B). Many combinations of acrylates and more challenging arylureas, however, did not produce the desired product in satisfactory yields, and the reaction still required the use of stoichiometric silver salts in addition to benzoquinone.

To overcome these limitations, further optimization of the catalyst system was conducted (Figure 5). A combination of $\mathrm{AgNO}_{3}$ or $\mathrm{AgOAc}$ and $\mathrm{BQ}$ was critical to obtain good yields of the same products formed earlier in water (vide supra), but as seen previously in the corresponding Suzuki-Miyaura reactions, a switch to EtOAc obviated the need for a silver salt. In the presence of BQ and $\mathrm{HBF}_{4}$, the reaction of $\mathbf{1 g}$ and acrylate $\mathbf{4}$ was efficiently catalyzed by $\mathrm{Pd}(\mathrm{OAc})_{2}$ (Figure 5, runs 3 and 4). Lower loadings of $\mathrm{BQ}$ and $\mathrm{HBF}_{4}$ also gave good results (Figure 5, runs 5 and 7). Much lower loading of $\mathrm{HBF}_{4}$, however, afforded a low yield of product 5 (Figure 5, run 8). In the absence of acid or BQ, the product was not obtained (Figure 5, runs 6 and 9). The pre-formed cationic palladium(II) complex, $\left[\mathrm{Pd}(\mathrm{MeCN})_{4}\right]\left(\mathrm{BF}_{4}\right)_{2}$, was also found to effectively catalyze the reaction between $\mathbf{1 g}$ and ester $\mathbf{4}$ at room temperature, without additional acid, although somewhat longer reaction times were necessary (Figure 5, run 10). Despite the presence of two poten- tially reactive ortho-aromatic $\mathrm{C}-\mathrm{H}$ bonds in $\mathbf{1 g}$, the mono-acrylated product was obtained exclusively.

Under optimized conditions, various acrylates and amides can be synthesized via $\mathrm{C}-\mathrm{H}$ activation reactions (Figure 6). Methyl acrylate, which did not show good general reactivity with arylureas under previous conditions, could be coupled in excellent yields (5i, 5j, 5k). As previously mentioned, a drawback characteristic of several ortho-directed $\mathrm{C}-\mathrm{H}$ activation crosscoupling approaches has been the undesired coupling at both sites ortho- to the directing group. These new conditions completely inhibited second-stage alkenylation, thereby generating singly derivatized arylureas in good yields $(\mathbf{5 l}, \mathbf{5 m}, \mathbf{5 n})$. Arylureas containing halogens, which are slightly electron-deficient but provide useful synthetic handles for subsequent functionalization, reacted cleanly to form the desired products $(\mathbf{5 p}$, $\mathbf{5 q}$ ). Arylureas bearing ortho-alkyl substituents also gave excellent yields $(\mathbf{5 0}, \mathbf{5 r})$, while acrylamides having simple amine or amino acid moieties also participated in cross-coupling reactions with the arylurea to produce the corresponding amide derivatives in moderate to good yields $(\mathbf{5 s}, \mathbf{5 t})$.

\section{Total synthesis of boscalid ${ }^{\circledR}$ via C-H activation}

The rationale behind the attention recently accorded $\mathrm{C}-\mathrm{H}$ activation chemistry has been based, in part, on its potential to streamline routes towards valuable synthetic targets. As a demonstration of the utility of our $\mathrm{C}-\mathrm{H}$ activation approach, we<smiles>C=CC(=O)OCCCCCCCCCCC(=O)Nc1ccc(OC)cc1</smiles>

$1 \mathrm{~g}$
4

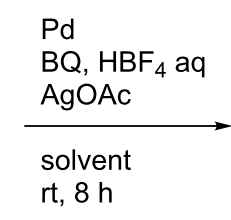

$\mathrm{R}=$

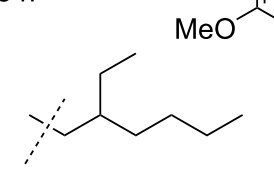<smiles>[R]OC(=O)/C=C/c1cc(OC)ccc1NC(=O)N(C)C</smiles>

\begin{tabular}{clcccl}
\hline run & cat & $\mathrm{BQ}$ & $\mathrm{AgOAc}$ & $\mathrm{HBF}_{4}$ & yield(\%) \\
\hline 1 & $\mathrm{Pd}(\mathrm{OAc})_{2}$ & 1 & 2 & 5 & $38^{\mathrm{a}}$ \\
2 & $\mathrm{Pd}(\mathrm{OAc})_{2}$ & 1 & 2 & 5 & 93 \\
3 & $\mathrm{Pd}(\mathrm{OAc})_{2}$ & 3 & 0 & 1 & $96(7 \mathrm{~h})$ \\
4 & $\mathrm{Pd}(\mathrm{OAc})_{2}$ & 3 & 0 & 1 & $97(4 \mathrm{~h})$ \\
5 & $\mathrm{Pd}(\mathrm{OAc})_{2}$ & 1.5 & 0 & 1 & $92(4 \mathrm{~h})$ \\
6 & $\mathrm{Pd}(\mathrm{OAc})_{2}$ & 0 & 0 & 1 & trace $(7 \mathrm{~h})$ \\
7 & $\mathrm{Pd}(\mathrm{OAc})_{2}$ & 3 & 0 & 0.5 & $93(7 \mathrm{~h})$ \\
8 & $\mathrm{Pd}(\mathrm{OAc})_{2}$ & 3 & 0 & 0.2 & $40(4 \mathrm{~h})$ \\
9 & $\mathrm{Pd}(\mathrm{OAc})_{2}$ & 3 & 0 & 0 & $0(20 \mathrm{~h})$ \\
10 & {$\left[\mathrm{Pd}(\mathrm{MeCN})_{4}\right]\left(\mathrm{BF}_{4}\right)_{2}$} & 3 & 0 & 0 & $88(20 \mathrm{~h})$
\end{tabular}


<smiles>CNC(=O)Nc1cc(C)ccc1/C=C/C(=O)OC</smiles>

5i: $93 \%(12 \mathrm{~h})$<smiles>[R]OC(=O)/C=C/c1ccccc1NC(=O)N(C)C</smiles>

5m: $95 \%(4 h)$

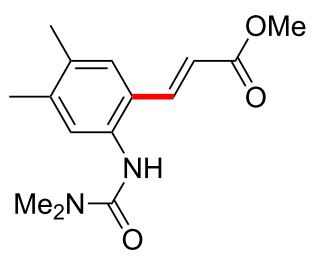

5j: $99 \%(12$ h)

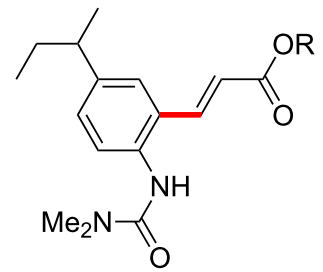

5n: $99 \%(20 h)$

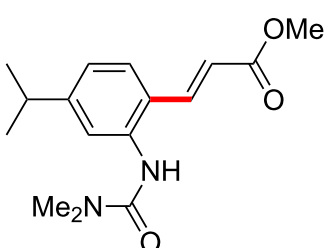

5k: $96 \%(12$ h)<smiles>[R]OC(=O)/C=C/c1cccc2c1N(C(N)=O)CC2</smiles>

5o: $99 \%(24 h)$<smiles>[R]OC(=O)/C=C/c1cc(OC)ccc1NC(=O)N(C)C</smiles>

5I: $97 \%(4 \mathrm{~h})$<smiles>[R]OC(=O)/C=C/c1ccc(Br)cc1NC(=O)N(C)C</smiles>

5q: $83 \%(24 h)$<smiles>[R]OC(=O)/C=C/c1cccc(C)c1NC(N)=O</smiles>

5r: $87 \%(48 \mathrm{~h})$<smiles>CCOC(=O)C(Cc1ccccc1)NC(=O)/C=C/c1cc(Cl)c(OC)cc1NC(=O)N(C)C</smiles>

5s: $71 \%(20 \mathrm{~h})$<smiles>[R]OC(=O)/C=C/c1cc(Cl)c(OC)cc1NC(=O)N(C)C</smiles>

5p: $89 \%(24 \mathrm{~h})$

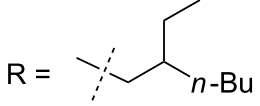<smiles>CCC(C)c1ccc(NC(=O)N(C)C)c(/C=C/C(=O)N(C)c2ccccc2)c1</smiles>

5t: $52 \%(20$ h)

Figure 6: Representative results in EtOAc. Conducted at rt in EtOAc with $10 \mathrm{~mol} \% \mathrm{Pd}(\mathrm{OAc})_{2}, \mathrm{HBF}_{4}$ (1 equiv), arylurea (1, $\left.0.25 \mathrm{mmol}\right), \mathrm{BQ}(3 \mathrm{equiv})$ and acrylate (2, 2.0 equiv).

chose to synthesize boscalid ${ }^{\circledR}$, a pesticide currently prepared on a yearly kiloton scale by means of a traditional Suzuki-Miyaura coupling. It is used to control a range of plant pathogens in broadacre and horticultural crops (Scheme 6) [207]. Felpin and co-workers have reported its synthesis starting from aryldiazonium salts [208], while the Heinrich group has employed a freeradical biaryl cross-coupling of diaminobenzene promoted by $\mathrm{TiCl}_{3}$ [209]. A number of additional syntheses can also be found in the literature $[86,210]$. Moreover, the BASF has patented routes using a traditional Suzuki-Miyaura cross-coupling in the presence of $0.5 \mathrm{~mol} \% \mathrm{Pd}$ catalyst to reach the same nitro-intermediate found in the Felpin route [211-213].

Many of these syntheses require large excesses of iron or other stoichiometric metals to obtain high yields (Scheme 6). As shown in Scheme 7, a synthesis that proceeds via a C-H activa- tion strategy, however, might provide a highly efficient, alternative route originating from just aniline. The corresponding phenylurea can be prepared in high yield (96\%), which is then subjected to C-H Suzuki-Miyaura coupling at room temperature $(91 \%)$. Sequential deprotection and acylation with 2-chloronicotinoyl chloride result in boscalid in four steps in an overall yield of $86 \%$, which compares favorably with all known routes to this pesticide shown in Scheme 6 [86,208-213].

\section{Mechanistic insight}

Although there have been a number of mechanistic studies on $\mathrm{C}-\mathrm{H}$ activation reactions involving neutral palladium species [34,108-119], those catalyzed by cationic palladium have been much less thoroughly examined. We hypothesized that our catalytic cycles for the Fujiwara-Moritani, arylboronic acid, and aryl iodide coupling reactions catalyzed by cationic palladium 

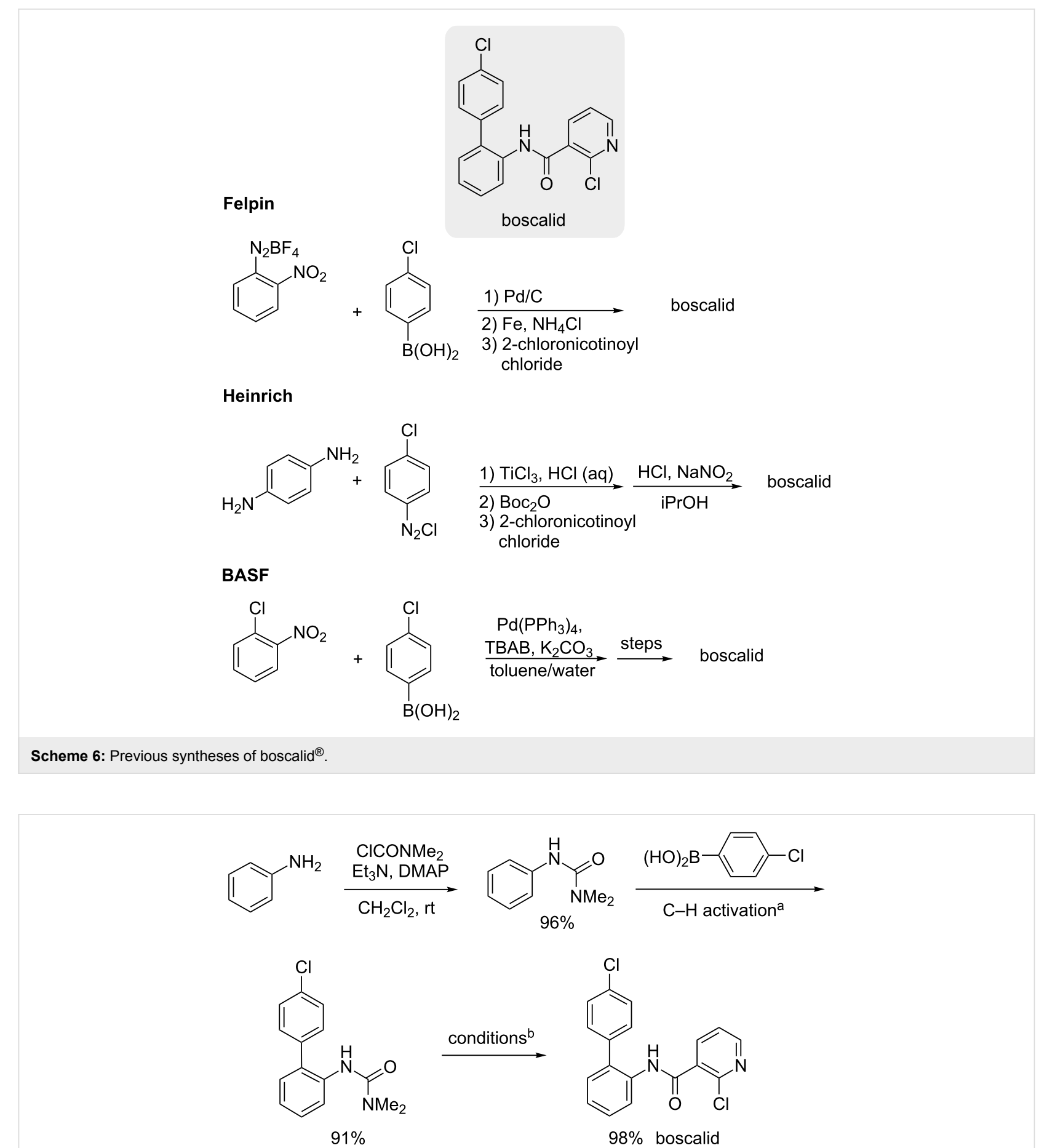

Scheme 7: Synthesis of boscalid ${ }^{\circledR}$. a Conducted at it for $20 \mathrm{~h}$ in EtOAc with $10 \mathrm{~mol} \%\left[\mathrm{Pd}(\mathrm{MeCN})_{4}\right]\left(\mathrm{BF}_{4}\right)_{2}, \mathrm{BQ}$ (5 equiv), arylurea $(\mathbf{1}, 0.25 \mathrm{mmol})$, and $\mathrm{ArB}(\mathrm{OH})_{2}\left(2,1.5\right.$ equiv). ${ }^{\mathrm{b}} \mathrm{NaOH}$, dioxane/water, reflux, then 2-chloronicotinoyl chloride, $\mathrm{Et}{ }_{3} \mathrm{~N}, \mathrm{THF}$, rt.

complexes are composed of three key steps; (1) aromatic $\mathrm{C}-\mathrm{H}$ activation by cationic palladium; (2) reaction of the resulting intermediate (a cationic palladacycle) with a corresponding reagent; and (3) re-generation of the active catalyst (Scheme 8). In order to test this hypothesis we explored the viability of each of these individual steps.

\section{The $\mathrm{C}-\mathrm{H}$ activation step}

Although aromatic $\mathrm{C}-\mathrm{H}$ bond activation through palladacycle [214] generation is a critical step in the ortho-directed, activation/cross-coupling sequence, many of its specific mechanistic features are still controversial. Previous studies with arylureas $[73,206,215]$ have formulated a palladacycle as the likely initial 


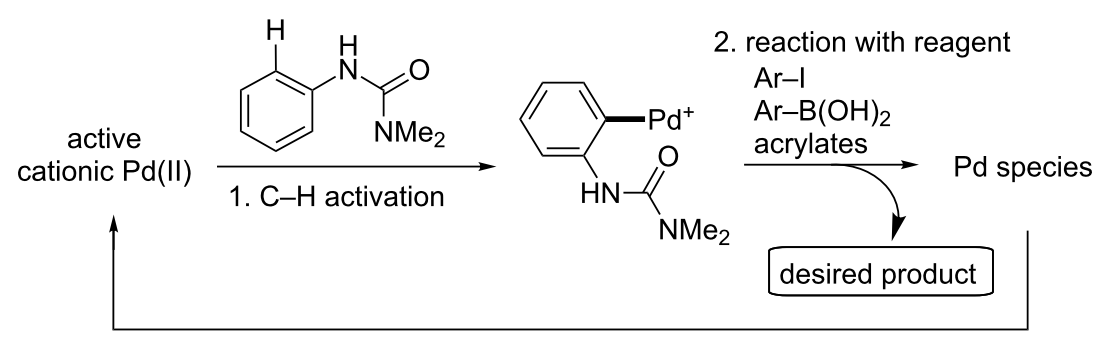

3. regeneration of active catalyst

Scheme 8: Hypothetical reaction sequence for cationic $\mathrm{Pd}(\mathrm{II})$-catalyzed aromatic $\mathrm{C}-\mathrm{H}$ activation reactions.

intermediate associated with palladation and subsequent $\mathrm{C}-\mathrm{H}$ bond cleavage.

In order to confirm palladacycle formation in our reactions with arylureas, the dicationic palladium complex $\left[\mathrm{Pd}(\mathrm{MeCN})_{4}\right]\left(\mathrm{BF}_{4}\right)_{2}$ was exposed to one equivalent of 3-methoxyphenylurea 1f at room temperature for 20 minutes (Scheme 9). This stoichiometric reaction led to the corresponding palladacycle 6 in $95 \%$ yield, without the aid of additives (i.e., no $\mathrm{Ag}$ salt or protic acid). In harmony, in situ-generated cationic palladium from the reaction of $\mathrm{Pd}(\mathrm{OAc})_{2}$ and $\mathrm{HBF}_{4}$ gave the same palladacycle upon addition of acetonitrile, as confirmed by NMR. The facile formation of this species supports the intermediacy of a palladacycle in the catalytic cycle. The structure of the isolated palladacycle was confirmed by X-ray analysis [216].

An ORTEP plot for palladacycle 6 is shown in Figure 7. The molecular structure consists of a Pd atom with an arylurea and two molecules of acetonitrile assembled in a square-planar geometry around the metal. The sum of the angles around $\mathrm{Pd}$ is $360.01^{\circ}$. The $\mathrm{C}(5)-\mathrm{Pd}-\mathrm{O}(2)$ angle $\left(91.98^{\circ}\right)$ is slightly larger than that of $\mathrm{N}(3)-\mathrm{Pd}-\mathrm{N}(4)\left(87.81^{\circ}\right)$, but it is similar to the angles of neutral $\mathrm{PdCl}_{2}\left(\mathrm{Ph}_{2} \mathrm{PCH}_{2} \mathrm{CH}_{2} \mathrm{CH}_{2} \mathrm{PPh}_{2}\right)(\mathrm{dppp})$ ) (angle of $\mathrm{P}-\mathrm{Pd}-\mathrm{P}$ : $90.58^{\circ}$ ) having a six-membered ring conformation [217], and palladacycles reported previously [73,206,215]. The length of the Pd-N4 bond, (2.126 $\AA$ ), is slightly longer than

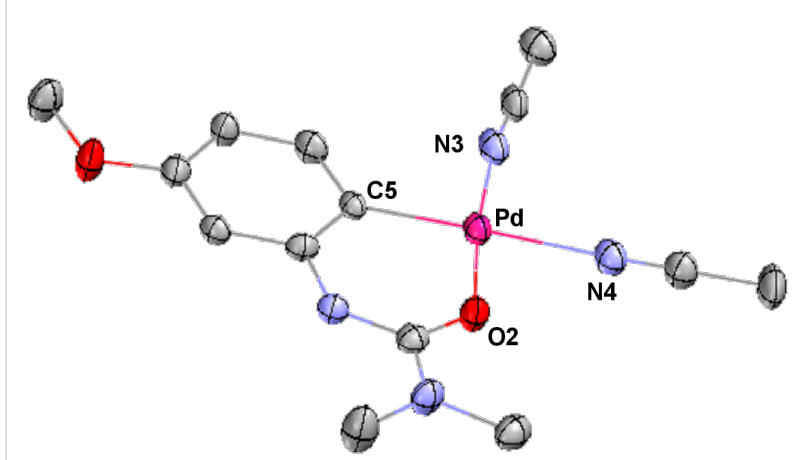

Figure 7: X-ray structure of palladacycle 6 with thermal ellipsoids at the $50 \%$ probability level. $\mathrm{BF}_{4}$ and hydrogen atoms were omitted for clarity. Selected bond length $(\AA): \mathrm{Pd}-\mathrm{C}(5)=1.980, \mathrm{Pd}-\mathrm{N}(3)=1.995$, $\mathrm{Pd}-\mathrm{N}(4)=2.126, \mathrm{Pd}-\mathrm{O}(2)=1.988$. Selected angles $\left(^{\circ}\right)$ : $\mathrm{C}(5)-\mathrm{Pd}-\mathrm{N}(3)=94.15, \mathrm{~N}(3)-\mathrm{Pd}-\mathrm{N}(4)=87.81, \mathrm{~N}(4)-\mathrm{Pd}-\mathrm{O}(2)=86.07$, $\mathrm{O}(2)-\mathrm{Pd}-\mathrm{C}(5)=91.98$.

those of $\mathrm{Pd}-\mathrm{N}(3), \mathrm{Pd}-\mathrm{C}(5), \mathrm{Pd}-\mathrm{O}(2)$ bonds, likely due to a trans effect of the strong $\sigma$-donor aryl group as has been observed in a related urea palladacycle $[73,215]$. The bond length of $\mathrm{Pd}-\mathrm{N}$ is $1.96 \AA$ in $\left[\mathrm{Pd}(\mathrm{MeCN})_{4}\right]\left(\mathrm{BF}_{4}\right)_{2}$.

NMR spectroscopic studies on the reaction between a cationic Pd(II) complex and an arylurea to generate a palladacycle are illustrated in Figure 8. The pure palladacycle from pre-formed cationic palladium $\left[\mathrm{Pd}(\mathrm{MeCN})_{4}\right]\left(\mathrm{BF}_{4}\right)_{2}$ is shown as spectrum in Figure 8A. Generally, monocationic arylpalladium(II) com-

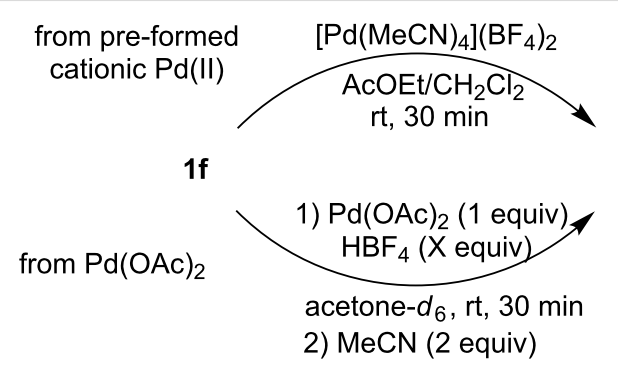

Scheme 9: Palladacycle formation.
95\% (>95\% conversion from 1 )

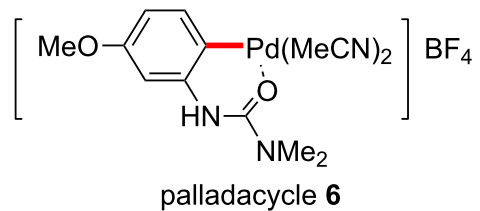

$95 \%$ conversion $(X=2)$, but $>80 \%$ of $1 \mathrm{f}$ in the absence of $\mathrm{HBF}_{4}$ 


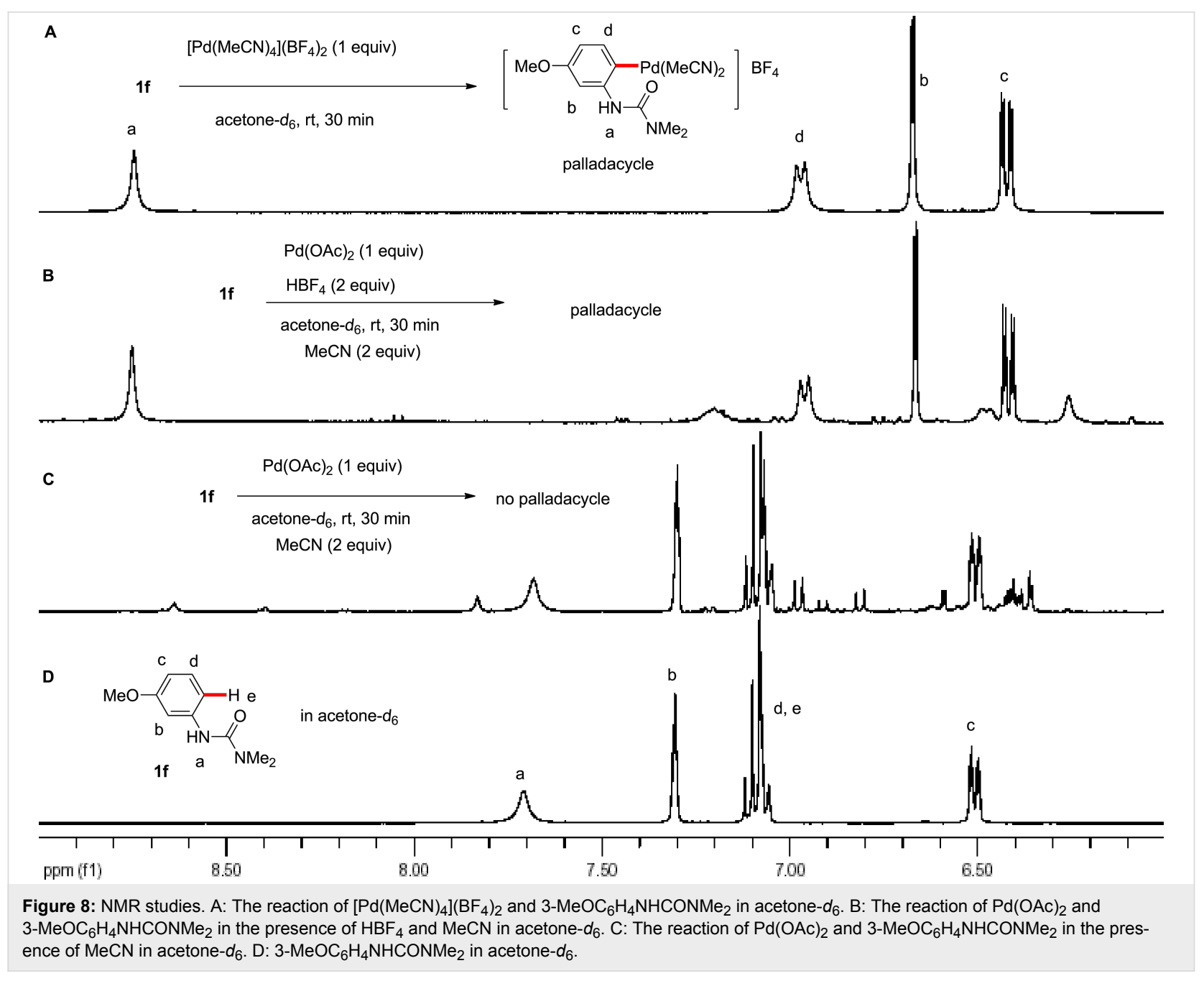

plexes without strongly coordinating ligands are unstable even at low temperatures [218-220]; nonetheless, this cationic palladacycle, aided by the presence of strongly coordinating $\mathrm{MeCN}$, was found to be quite stable at room temperature. While the in situ generated cationic palladium species from the reaction of $\mathrm{Pd}(\mathrm{OAc})_{2}$ and $\mathrm{HBF}_{4}$ gave the same palladacycle upon treatment with the arylurea (spectrum Figure $8 \mathrm{~B}$ ), the reaction in the absence of $\mathrm{HBF}_{4}$ did not result in palladacycle formation (spectrum Figure 8C). Here, essentially no conversion of the starting material was detected by ${ }^{1} \mathrm{H}$ NMR in acetone- $d_{6}$ (spectrum Figure 8D). Indeed, for reactions starting from $\mathrm{Pd}(\mathrm{OAc})_{2}$, no cross-coupling product was observed without adding a $\mathrm{BF}_{4}{ }^{-}$ source for the Fujiwara-Moritani reaction (Figure 5, run 9), Suzuki-Miyaura coupling (Scheme 4), and arylation with aryl iodide $[121,122,150] . \mathrm{HBF}_{4}$ apparently acts as an acetate scavenger to generate the active cationic palladium(II) species (Scheme 10).

As discussed previously herein, there are several routes available for cyclopalladation and $\mathrm{C}-\mathrm{H}$ bond cleavage, most notably

$$
\mathrm{Pd}(\mathrm{OAc})_{2} \underset{-\mathrm{AcOH}}{\stackrel{\mathrm{HBF}_{4}}{\longrightarrow}}\left[\mathrm{Pd}(\mathrm{II}) \mathrm{L}_{n}\right]\left(\mathrm{BF}_{4}\right)_{2}
$$

Scheme 10: The generation of cationic $\mathrm{Pd}(\mathrm{II})$ from $\mathrm{Pd}(\mathrm{OAc})_{2}$

the concerted metalation-deprotection (CMD) or electrophilic palladation pathways (Scheme 1) [221-224]. Although control experiments had previously indicated the importance of conditions involving cationic palladium for achieving overall reaction conversion, our studies of palladacycle formation suggest that a cationic palladium catalyst is specifically required for the initial C-H activation step itself. Since the crystal structure of 6 (Figure 7) is indicative of a monocationic palladacycle, the cationicity of the metal may still play a role as well in subsequent steps. However, the much higher reactivity of a cationic Pd species (even under acetate-free conditions), the lack of effectiveness of $\mathrm{Pd}(\mathrm{OAc})_{2}$ alone in palladacycle formation, and the observed reactivity trends that strongly favor more electron-rich arylureas, all appear to be most consistent with an 
electrophilic palladation pathway over a CMD mechanism (Scheme 11). However, it is appreciated that further study might provide additional insight on this point.

\section{Reactions of palladacycle $\mathbf{6}$ with $\mathrm{Ph}-\mathrm{I}$, $\mathrm{PhB}(\mathrm{OH})_{2}$, and an acrylate}

Having demonstrated the potential for facile palladacycle formation at room temperature, we next examined the reactivity of this intermediate with coupling partners for each of the three reaction types studied. Stoichiometric reactions between the isolated palladacycle 6 and an acrylate or arylboronic acid were first attempted at room temperature (Scheme 12). Initial experiments, however, resulted in no formation of the desired products. Although the palladacycles were subjected to various conditions in the presence of $\mathrm{BQ}$ and $\mathrm{HBF}_{4}$, the anticipated reaction did not proceed from isolated catalyst complexes containing the stabilizing ligand $\mathrm{MeCN}$.

Although the initial $\mathrm{C}-\mathrm{H}$ activation step proceeded readily in the presence of $\mathrm{MeCN}$ in these stoichiometric reactions, subsequent reactions of the palladacycle with acrylates, arylboronic acids, and aryl iodides appeared to be significantly suppressed by the presence of stoichiometric $\mathrm{MeCN}$. The inhibitory effect of this ligand had been previously observed in the coupling reactions of aryl iodides (in which even $40 \mathrm{~mol} \%$ of $\mathrm{MeCN}$ was enough to almost completely shut down the reaction) [121]. In a cationic palladium(II) complex-catalyzed 1,4-addition of arylsilane, the nitrile-free cationic Pd(II) catalyst was much more effective than a $\mathrm{PhCN}$-containing cationic palladium(II) complex towards transmetallations with arylsilicon-containing partners and insertion of mono-cationic arylpalladium(II) species into olefins [136]. The detrimental effect of $\mathrm{MeCN}$ under our $\mathrm{C}-\mathrm{H}$ activation conditions was further established through a series of reactions as illustrated in Scheme 13. Under optimized conditions previously determined, where $\mathrm{C}-\mathrm{H}$ functionalized products were obtained in good yields, in the presence of added $\mathrm{MeCN}$ (1 equiv relative to 1f) all three reactions were completely inhibited, in all likelihood due to its strong coordinating ability as a ligand on cationic palladium.

On the other hand, when nitrile-free conditions were applied to urea 1f, with in situ-generated palladacycle (from $\mathrm{Pd}(\mathrm{OAc})_{2}$ and

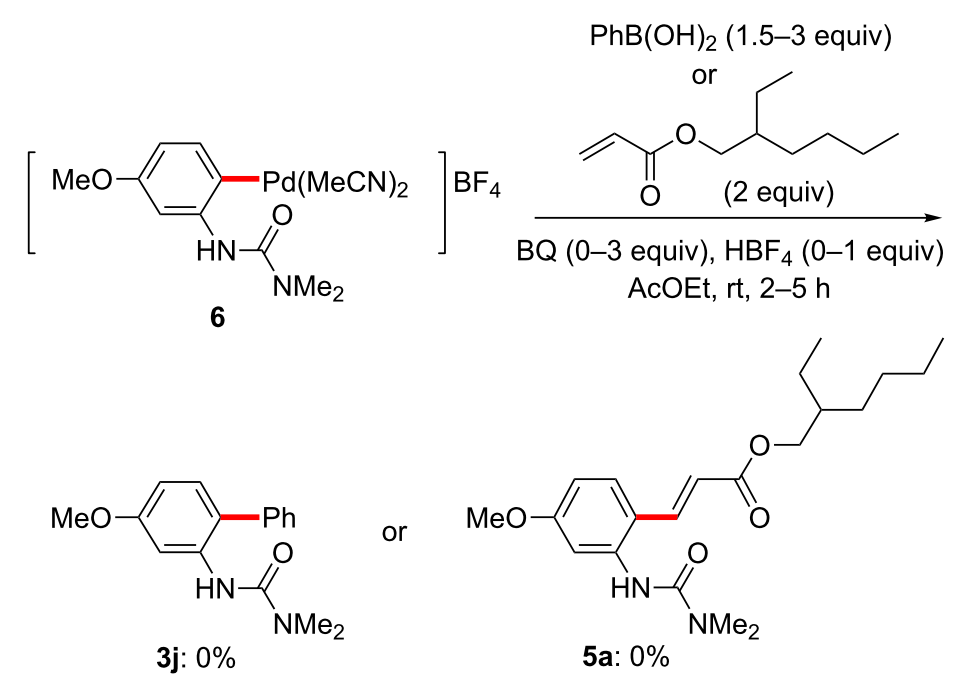




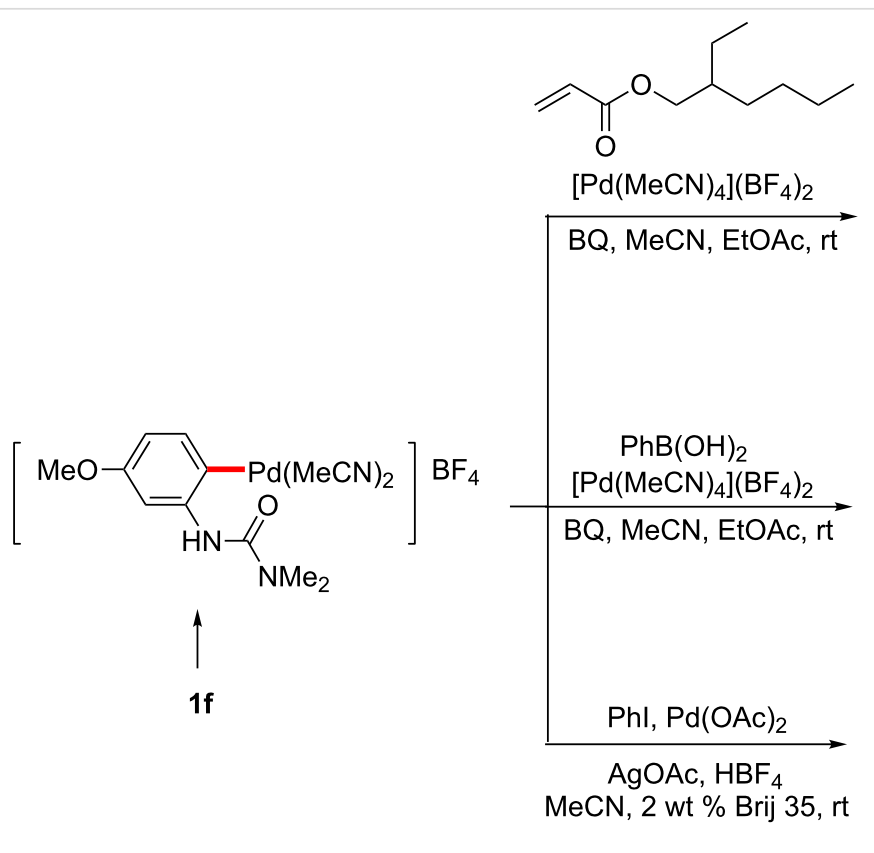

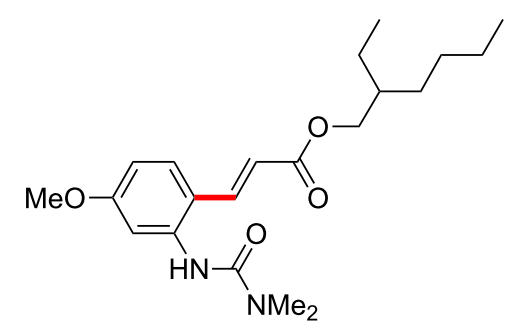

5a: trace
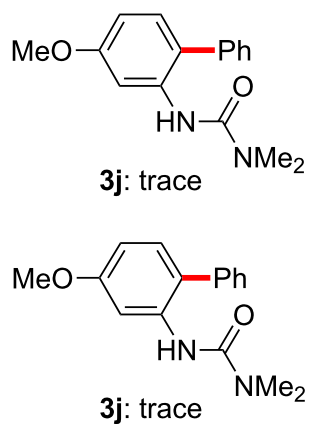

3j: trace

Scheme 13: The impact of $\mathrm{MeCN}$ on $\mathrm{C}-\mathrm{H}$ activation/coupling reactions.

$\mathrm{HBF}_{4}$; Figure 8), followed by addition of the usual reagents, each reaction proceeded to give the anticipated acrylated/ arylated product (Scheme 14; unoptimized yields). Notably, all three stoichiometric reactions now proceeded in the absence of other additives, such as BQ or Ag(I) salts, which are required for the catalytic versions to proceed efficiently.

Although Lloyd-Jones and Booker-Milburn also reported the reaction of a urea-derived palladacycle and arylboronic acid in the presence of base in THF under reflux conditions to produce the corresponding coupling product, our cationic palladacycle underwent coupling without added base (Scheme 15) [178]. In fact, it has been previously shown that cationic palladium species can undergo transmetalation with an arylboronic acid in the absence of base even at $0{ }^{\circ} \mathrm{C}[219,220]$. Wu and co-workers have also reported the interesting reactivities of neutral palladacycles with arylboronic acids (Scheme 15). Under their conditions, BQ and high temperature were critical to obtain the prod-

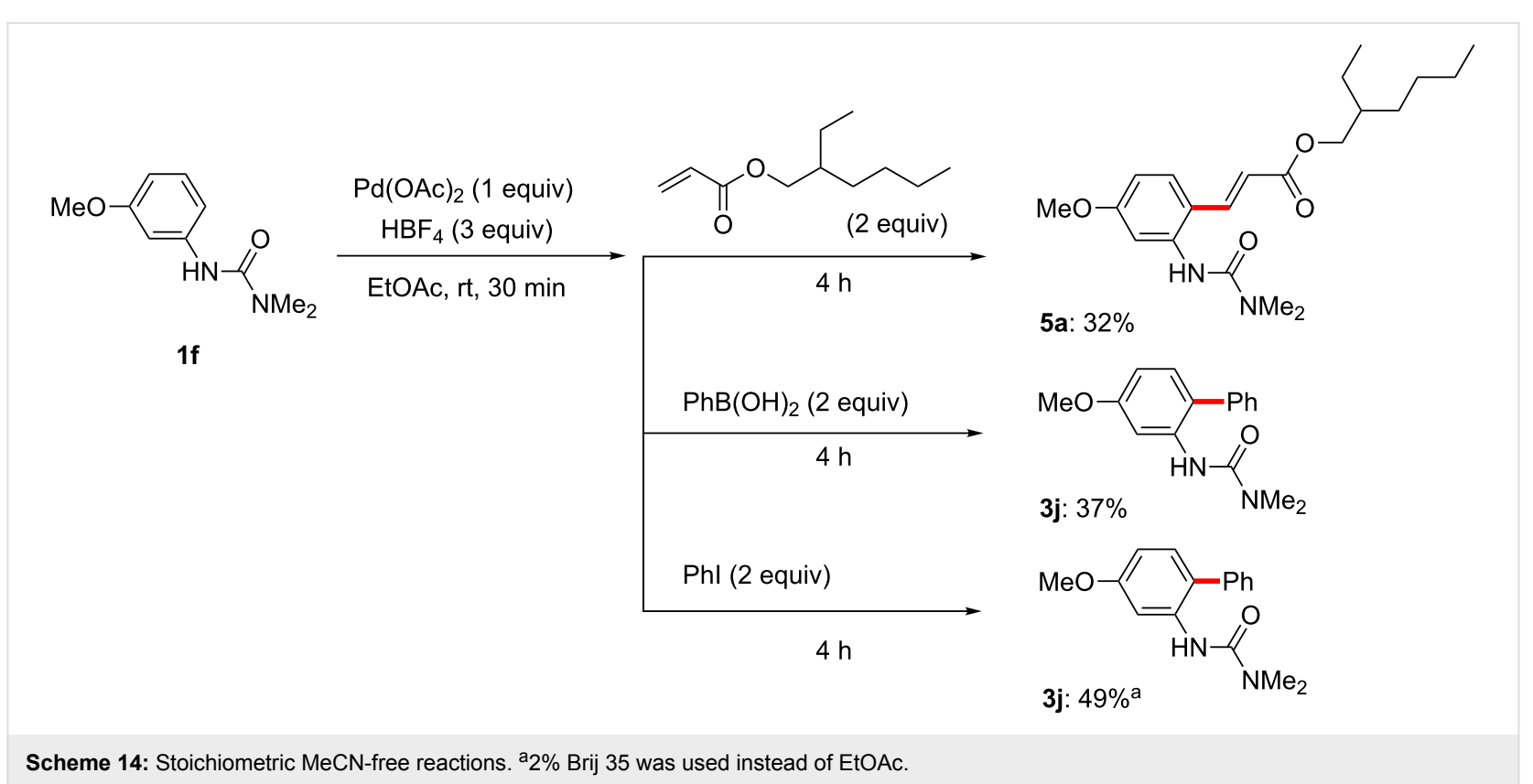




\section{Lloyd-Jones}

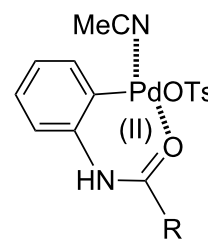<smiles>[R]C(=O)Nc1ccccc1Br</smiles>

Wu

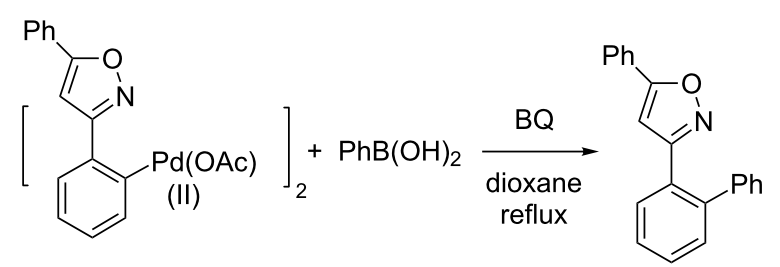

Scheme 15: The reactions of divalent palladacycles.

uct from their 5-membered isoxazoline-containing palladacycle $[160,168,225]$. Although BQ is sometimes used as a ligand for palladium to accelerate reductive elimination [103,226-230], its presence was not necessary in our stoichiometric reaction of a cationic 6-membered ring palladacycle.

\section{Regeneration of active catalyst; the roles of additives $\mathrm{BQ}, \mathrm{AgOAc}$, and $\mathrm{HBF}_{4}$}

As shown in previous sections herein, both the formation of palladacycles from arylureas and their subsequent coupling reactions with acrylates, arylboronic acids, and aryl iodides proceed under stoichiometric palladium conditions in the absence of additives, such as BQ and AgOAc, which had been necessary in the corresponding optimized catalytic reactions. To establish the roles of these additives, the reaction of the palladacycle in the presence of excesses of both coupling partners was carried out (Scheme 16). In Fujiwara-Moritani and Suzuki-Miyaura coupling reactions, 41 and $39 \%$ of the products (isolated yields based on the palladacycle) were obtained, respectively, in the absence of $\mathrm{BQ}$, indicating that no catalyst turnover was occurring without this additive. When 20 equivalents of BQ were added, along with the coupling partners, however, $847 \%(\mathrm{TON}=8.5)$ and $467 \%(\mathrm{TON}=4.7)$ yields of the products were obtained, respectively, supporting a key role for $\mathrm{BQ}$ in regeneration of the active dicationic species $\left(\mathrm{PdL}_{4}\left(\mathrm{BF}_{4}\right)_{2}\right)$.

Benzoquinone (BQ) has been well studied as an oxidant for $\operatorname{Pd}(0)$ to $\mathrm{Pd}(\mathrm{II})$ processes, generating hydroquinone as a byproduct. For the Fujiwara-Moritani coupling, addition of the palladacycle 6 to an acrylate followed by $\beta$-hydride elimination and reductive elimination of $\mathrm{HPd}^{+} \mathrm{BF}_{4}^{-}$would result in a $\mathrm{Pd}(0)$ species unable to participate in palladacycle formation until it is oxidized by $\mathrm{BQ}$ to $\mathrm{Pd}^{2+}\left(\mathrm{BF}_{4}\right)_{2}$, whereupon it reacts with another equivalent of arylurea (Scheme 17) [231]. Similarly, BQ's role in $\mathrm{C}-\mathrm{H}$ coupling of boronic acids would likely be to oxidize $\operatorname{Pd}(0)$ to $\operatorname{Pd}(\mathrm{II})$ after the product forming step (Scheme 18). Transmetallation between the palladacycle and arylboronic acid followed by reductive elimination would give the expected product and $\operatorname{Pd}(0)$, where the metal can be subsequently oxidized with BQ.

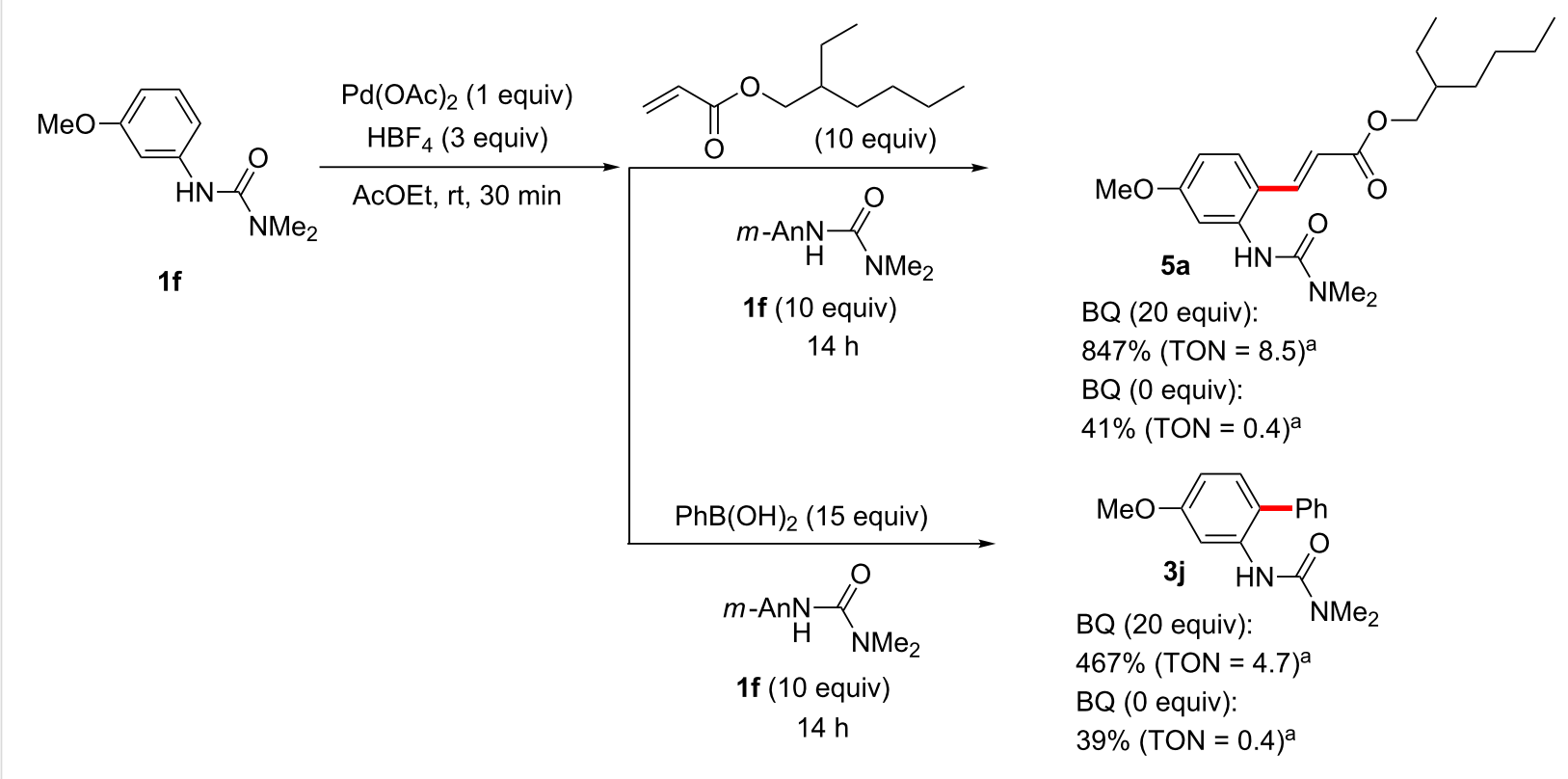

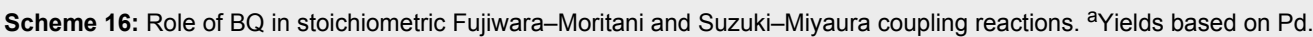




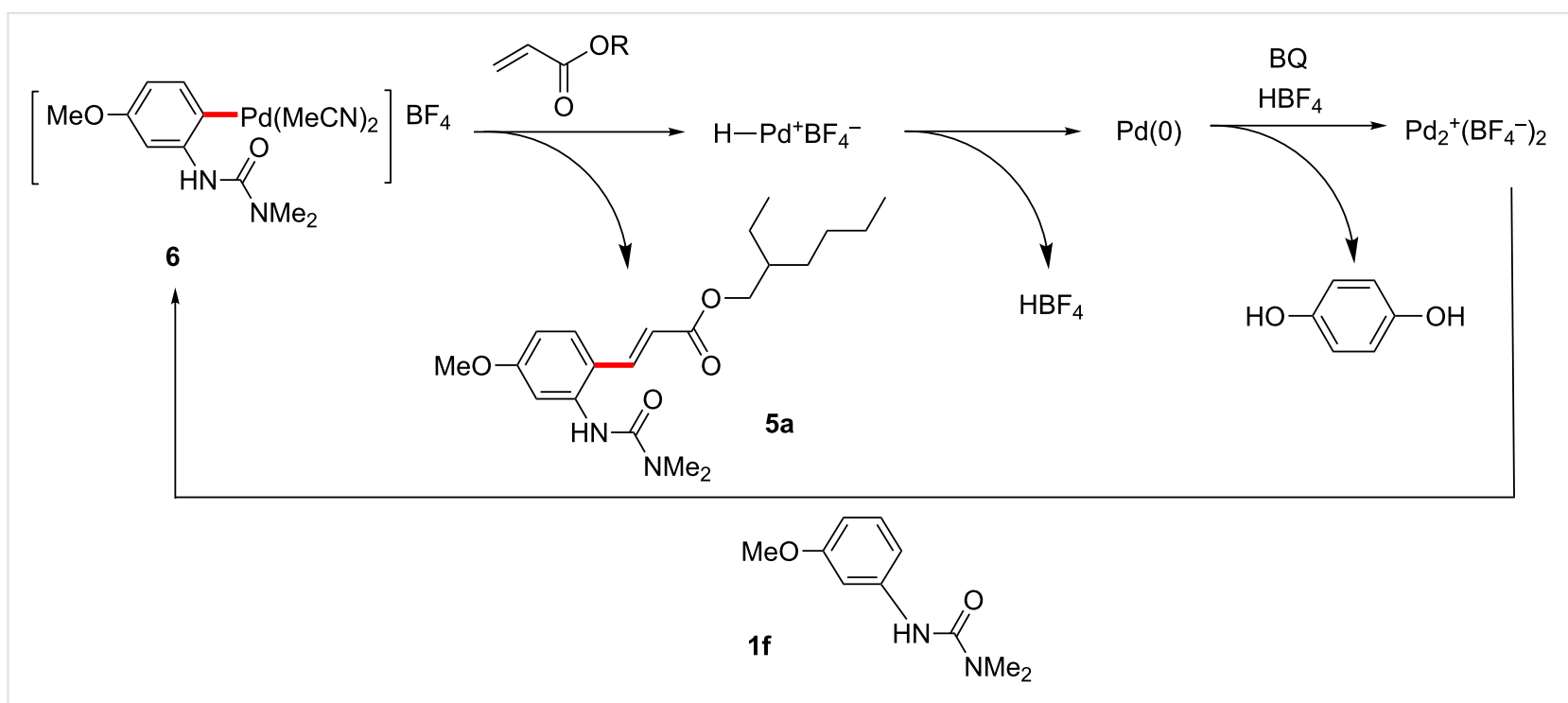

Scheme 17: Proposed role of BQ in Fujiwara-Moritani reactions.

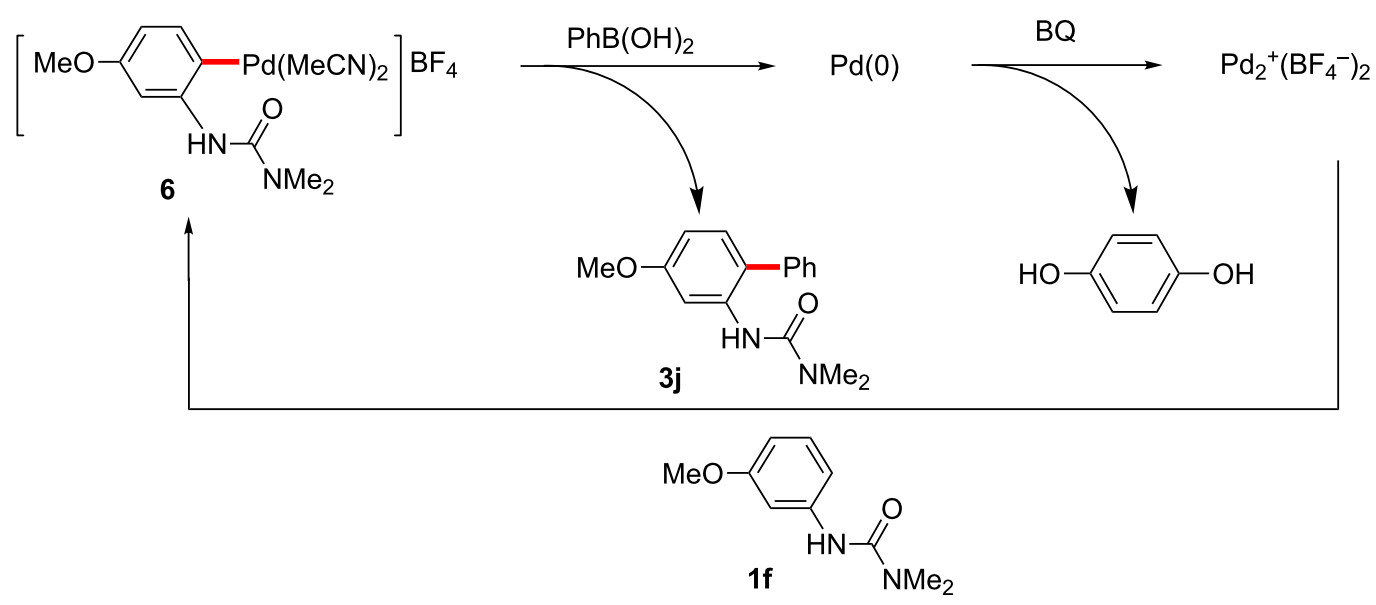

Scheme 18: Proposed role of $B Q$ in Suzuki-Miyaura coupling reactions.

In the reaction with aryl iodides, when an excess of coupling partner was employed, a yield of ca. $90 \%(\mathrm{TON}=0.9)$ of the product was obtained with or without additional $\mathrm{HBF}_{4}$ (Scheme 19), in this case indicating that no catalyst turnover was occurring in the absence of a $\mathrm{Ag}(\mathrm{I})$ salt. Surprisingly, when 15 equivalents of AgOAc were added along with an excess of both coupling partners, but without the addition of $\mathrm{HBF}_{4}$ beyond the three equivalents required for initial palladacycle formation, no coupling product was observed. Under these conditions, a large excess of acetate anion relative to $\mathrm{BF}_{4}{ }^{-}$ would exist, which may decrease the cationicity of the cationic palladium(II) species formed in the initial cyclopalladation (Scheme 20), or otherwise disrupt the reaction sequence subsequent to palladacycle formation. On the other hand, the reaction in the presence of both silver salt and excess of $\mathrm{HBF}_{4}$ gave the corresponding product in $342 \%$ yield relative to palladium $(\mathrm{TON}=3.4)($ Scheme 19).

Based on these results, the proposed roles of silver and acid are shown in Scheme 21. After the coupling of the palladacycle and aryl iodide, $\mathrm{I}_{-} \mathrm{Pd}^{+} \mathrm{BF}_{4}{ }^{-}$is generated, which is catalytically inac-

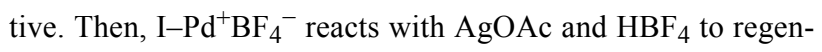
erate active cationic $\mathrm{Pd}^{2+}\left(\mathrm{BF}_{4}^{-}\right)_{2}$. Under this proposed sequence, AgOAc would primarily act, therefore, as an iodide scavenger.

In our previous studies it was found that when $\mathrm{AgBF}_{4}$ was used in place of AgOAc under optimized conditions for $\mathrm{C}-\mathrm{H}$ arylation with aryl iodides, $\mathrm{HBF}_{4}$ (or any other added acid) was unnecessary for the catalytic reaction to occur. Here, since 


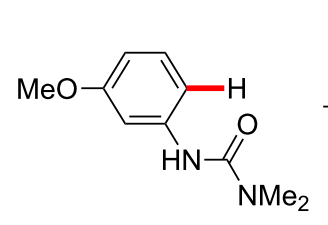

$1 \mathrm{f}$
$\mathrm{Pd}(\mathrm{OAc})_{2}$ (1 equiv)

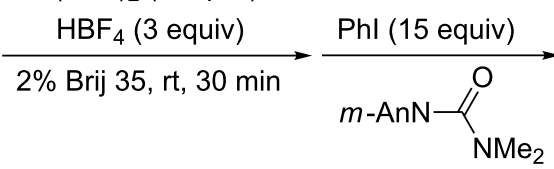

$1 f$ (10 equiv)

$14 \mathrm{~h}$<smiles>COc1ccc(-c2ccccc2)c(NC(C)=O)c1</smiles>

3j

\begin{tabular}{ccrr} 
AgOAc (equiv) & $\mathrm{HBF}_{4}$ (equiv) & yield $^{\mathrm{a}}$ & \multicolumn{1}{c}{ TON } \\
\hline 15 & 50 & 342 & 3.4 \\
0 & 50 & 87 & 0.9 \\
15 & 0 & 0 & 0 \\
0 & 0 & 94 & 0.9
\end{tabular}

Scheme 19: Stoichiometric C-H arylation of iodobenzene. ${ }^{\text {aY }}$ Yields based on Pd.

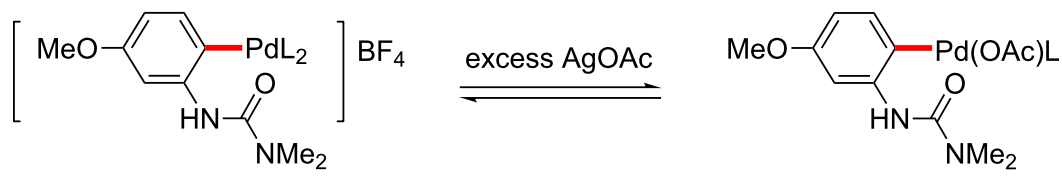

Scheme 20: Impact of acetate on the cationicity of Pd.

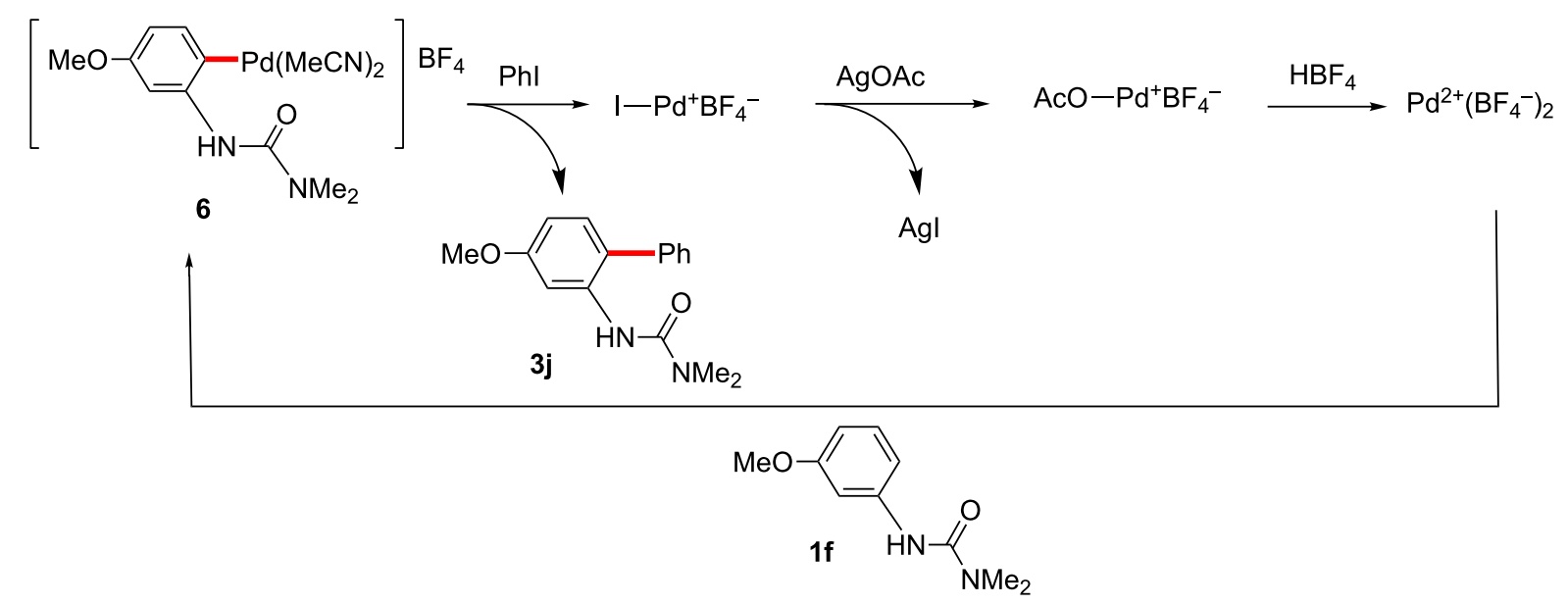

Scheme 21: Roles of additives in $\mathrm{C}-\mathrm{H}$ arylation.

$\mathrm{AgBF}_{4}$ apparently reacts with $\mathrm{I}-\mathrm{Pd}^{+} \mathrm{BF}_{4}^{-}$to produce catalytically active $\mathrm{Pd}^{2+}\left(\mathrm{BF}_{4}\right)_{2}{ }^{-}$(Scheme 22$)$, and there are no stoichiometric quantities of competing acetate anions, additional acid is not needed to produce and maintain active catalyst.

\section{Proposed mechanisms}

Our results have demonstrated that a dicationic palladium complex effectively catalyzes $\mathrm{C}-\mathrm{H}$ activation of arylureas at room temperature. Based on these studies of the major steps for each reaction, proposed catalytic cycles are illustrated below.
Fujiwara-Moritani reactions. At the first stage of the catalytic cycle, an active divalent cationic palladium species is generated from the reaction of a neutral complex, $\mathrm{Pd}(\mathrm{OAc})_{2}$, and $\mathrm{HBF}_{4}$ [232]. This reaction results in the formation of a monocationic arylpalladium(II) palladacycle, likely via a Wheland-like intermediate (Scheme 23) [233-237]. The product-forming portion of the cycle may proceed in a manner resembling a traditional Heck cross-coupling. In this case, addition of the palladacycle to an acrylate followed by $\beta$-hydride elimination yields the corresponding product $\mathbf{5}$. As previously demon- 


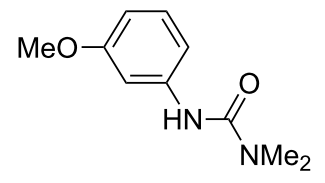<smiles>COc1ccc(I)cc1</smiles>

$1 f$

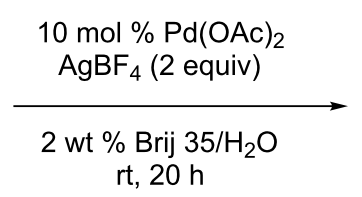

$\mathrm{rt}, 20 \mathrm{~h}$

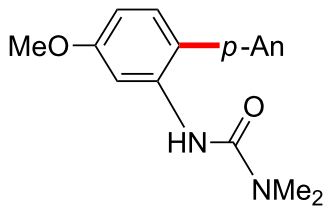

3h: $40 \%($ TON $=4)$

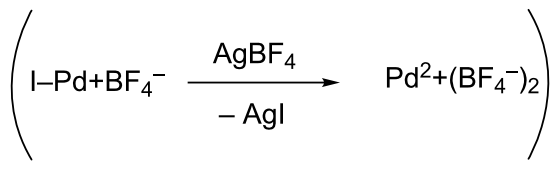

Scheme 22: Cross-coupling in the presence of $\mathrm{AgBF}_{4}$.

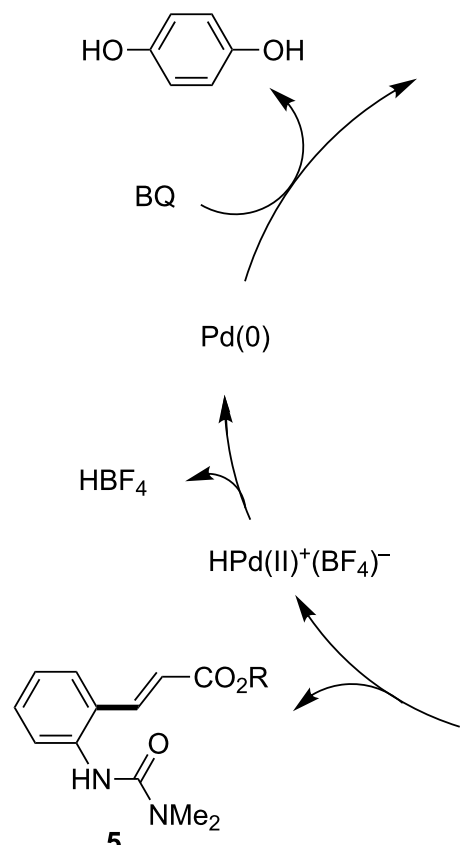

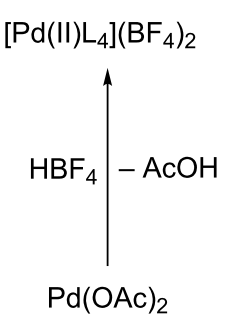

$\mathrm{Pd}(\mathrm{OAc})_{2}$

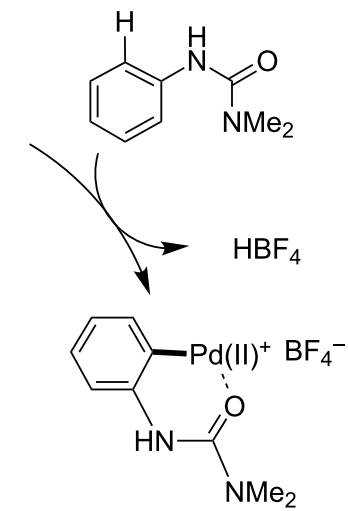

$\mathrm{BF}_{4}^{-}$

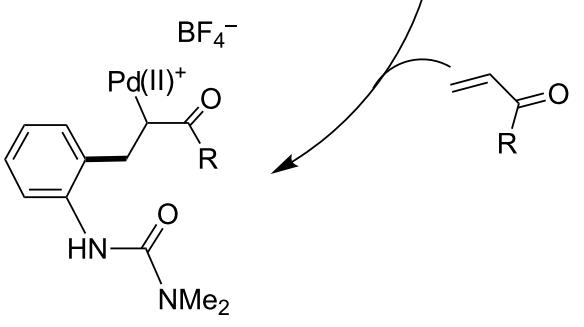

Scheme 23: A proposed catalytic cycle for Fujiwara-Moritani reactions.

strated in palladium-catalyzed Mizoroki-Heck reactions [238240 ], insertion of a alkenyl double bond into $\mathrm{C}-\mathrm{Pd}^{+}$present within the cationic palladacyle is facile, owing to the high Lewis acidity of the metal center. This is a noteworthy advantage associated with the use of cationic palladium(II) catalysts. Finally, BQ oxidizes the $\operatorname{Pd}(0)$ that is reductively eliminated from the $\mathrm{HPd}(\mathrm{II})^{+} \mathrm{BF}_{4}{ }^{-}$formed to regenerate the active cationic palladium species $\mathrm{Pd}^{2+}\left(\mathrm{BF}_{4}\right)_{2}{ }^{-}$.

C-H boronic acid coupling reactions. Unlike traditional Suzuki-Miyaura coupling reactions [241-243], C-H coupling reactions catalyzed by a cationic palladium(II) complex require an oxidant instead of a strong base, but otherwise likely share a number of features with this widely used $\mathrm{C}-\mathrm{C}$ bond-forming process. The reaction also presumably starts from the generation of a cationic palladacycle, which may undergo a facile transmetalation with an arylboronic acid without prior activation by base (Scheme 24) [241-248]. This step is followed by reductive elimination of a diarylpalladium(II) species, affording the coupling product and $\operatorname{Pd}(0)$. The resulting $\operatorname{Pd}(0)$ is then oxidized with $\mathrm{BQ}$ to regenerate the dicationic palladium species, which can re-enter the catalytic cycle.

Arylation with an aryl iodide. Coupling reactions of aryl iodides have fewer similarities in terms of traditional cross-coupling reactions compared with features characteristic of other room temperature $\mathrm{C}-\mathrm{H}$ activations we have studied, and are more difficult to rationalize with a $\mathrm{Pd}(\mathrm{II}) / \mathrm{Pd}(0)$ catalytic cycle. 


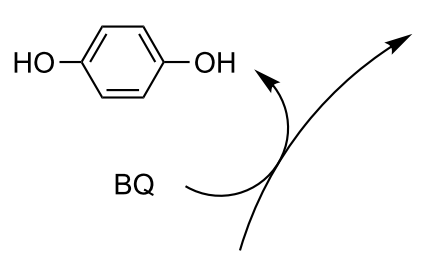

$\left[\mathrm{Pd}(\mathrm{MeCN})_{4}\right]\left(\mathrm{BF}_{4}\right)_{2}$
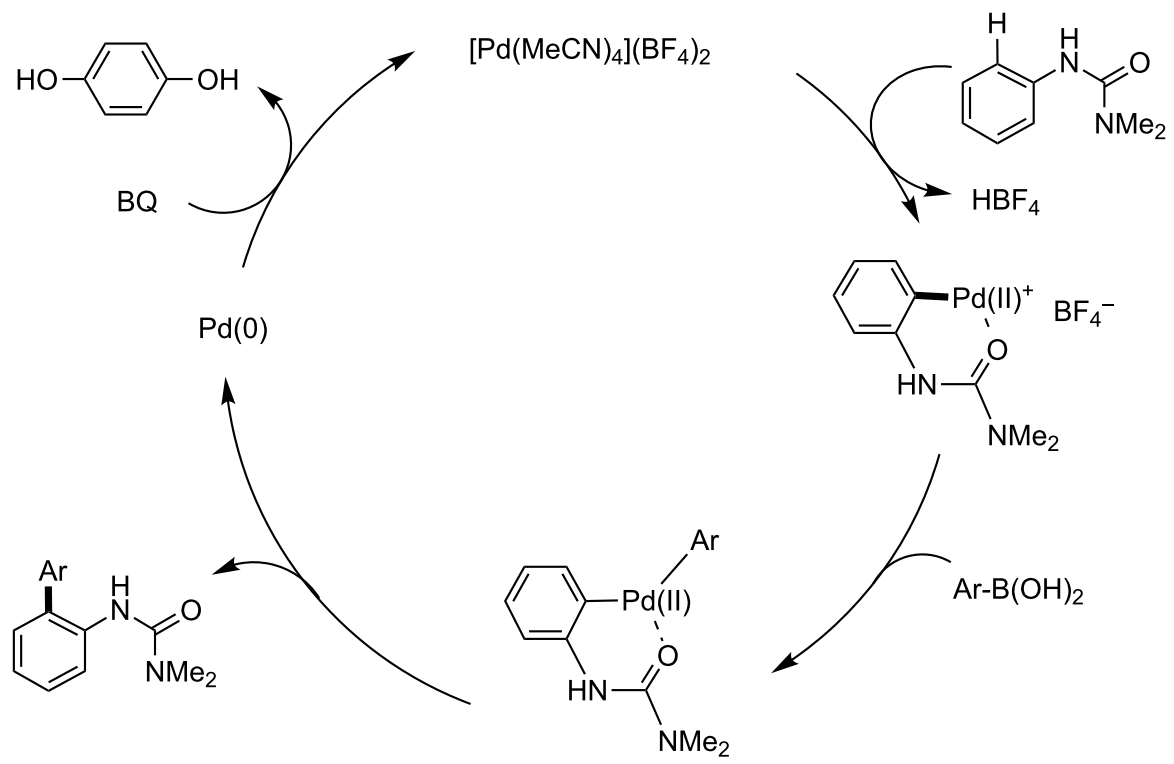

Scheme 24: Proposed catalytic cycle of C-H activation/Suzuki-Miyaura coupling reactions.

Hence, a possible $\mathrm{Pd}(\mathrm{II}) / \mathrm{Pd}(\mathrm{IV})$ catalytic cycle, similar to that previously proposed by Daugulis [8], is proposed below (Scheme 25). A mono-cationic palladium intermediate reacts with the aryl iodide, albeit in a poorly understood step of the sequence. Stoichiometric studies reveal that this step occurs in the absence of $\mathrm{AgOAc}$, and in fact its presence in excess relative to $\mathrm{HBF}_{4}$ inhibits the reaction (Scheme 19). In one possible pathway, an oxidative addition to the aryl iodide would provide a $\mathrm{Pd}(\mathrm{IV})$ intermediate, which could then rapidly reductively elim- inate in the $\mathrm{C}-\mathrm{C}$ bond forming step. The resulting $\mathrm{I}-\mathrm{Pd}(\mathrm{II})-\mathrm{X}$ species could then be converted back to the active cationic palladium species through reactions with the silver salt and $\mathrm{HBF}_{4}$ (or in situ generated $\mathrm{AgBF}_{4}$ ).

The specific nature of the reaction between the palladacycle and aryl iodide and resulting intermediate is lacking in details. It is known that divalent palladacycles react with alkyl iodides or diaryliodonium salts, and this process likely involves a $\mathrm{Pd}(\mathrm{IV})$

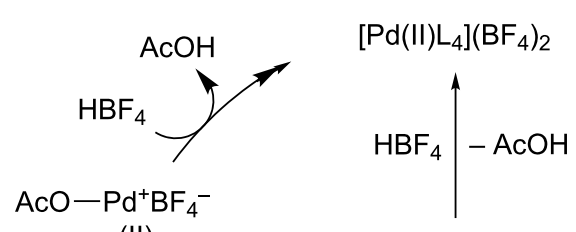

(II)<smiles>CC(C(=O)OCc1ccccc1)C(=O)OCc1ccccc1</smiles>

(II)

$\operatorname{Pd}(\mathrm{OAc})_{2}$<smiles>CCC1C(C)[C@@H]1CC</smiles><smiles>CN(C)C(=O)Nc1ccccc1Br</smiles>

Scheme 25: A proposed catalytic cycle for $\mathrm{C}-\mathrm{H}$ arylation involving a $\mathrm{Pd}(\mathrm{IV})$ intermediate. 
intermediate. Tremont and co-workers previously proposed a $\mathrm{Pd}(\mathrm{IV})$ intermediate in $\mathrm{C}-\mathrm{H}$ alkylation of acetoanilides and alkyl iodides [172]. In this case the reaction of a divalent palladacycle and MeI readily occurred at room temperature and was shown not to proceed through a radical pathway. Notably, in 2011 Vicente and co-workers obtained the crystal structure of a Pd(IV) complex obtained by the room temperature oxidative addition of an internally-chelated $\mathrm{Pd}(\mathrm{II})$ species into an aryl iodide, and demonstrated this species' competence as a precatalyst for C-H olefinations. Liu [73] and Sanford reported the stoichiometric reaction of palladacycles and aryliodonium salts at high temperature to give the corresponding products through $\mathrm{Pd}(\mathrm{II}) / \mathrm{Pd}(\mathrm{IV})$ or $\mathrm{Pd}(\mathrm{III}) / \mathrm{Pd}(\mathrm{III})$ dimeric species bridged by acetates (Scheme 26) $[68,175,249,250]$. Sequences involving $\mathrm{Pd}(\mathrm{III})$ intermediates have been suggested as alternatives to $\mathrm{Pd}(\mathrm{II}) / \mathrm{Pd}(\mathrm{IV})$ cycles in some cases, but most well-studied examples involve Pd(III)/Pd(III) dimers formed with the aid of bridging anionic ligands such as acetate or nitrate $[251,252]$ that do not match as well with the cationic palladium conditions employed here. Silver-mediated one electron oxidations to form monomeric Pd(III) complexes have also been studied [251], but the successful implementation of silver-free conditions with stoichiometric palladium herein would appear to eliminate this as a key step. To the best of our knowledge, the existence of $\mathrm{Pd}(\mathrm{IV})$ complexes has yet to be conclusively demonstrated from the oxidative addition of anilide-derived, divalent palladacycles into aryl halides, although formation of octahedral Pd(IV) complexes from $N$-substituted biphenyl palladacycles that possess similar highly planar structures as found in the urea-derived palladacycle (Figure 7) have been well studied [253-255].

\section{Conclusion}

In conclusion, we have demonstrated that a dicationic palladium complex enables facile $\mathrm{C}-\mathrm{H}$ activation reactions of arylureas with aryl iodides, arylboronic acids, and acrylates at room temperature. In many cases nanomicelles in water can be used in place of organic solvents, allowing for some of the mildest and environmentally responsible conditions yet achieved in $\mathrm{C}-\mathrm{H}$ activation chemistry. The practical value of this approach has been further demonstrated with an efficient, streamlined application to the synthesis of the herbicide boscalid. Mechanistic investigations revealed that a dicationic $\mathrm{Pd}(\mathrm{II})$ complex reacts readily with an arylurea to rapidly produce a mono-cationic palladacycle at room temperature, and this likely, catalytically competent species has been characterized by X-ray crystallography. Experiments revealed that a highly cationic palladium complex is required for the formation of this palladacycle at room temperature. While some key steps, including the precise nature of the reaction between this cationic palladacycle and aryl iodides, require further clarification, studies using stoichiometric palladium have provided

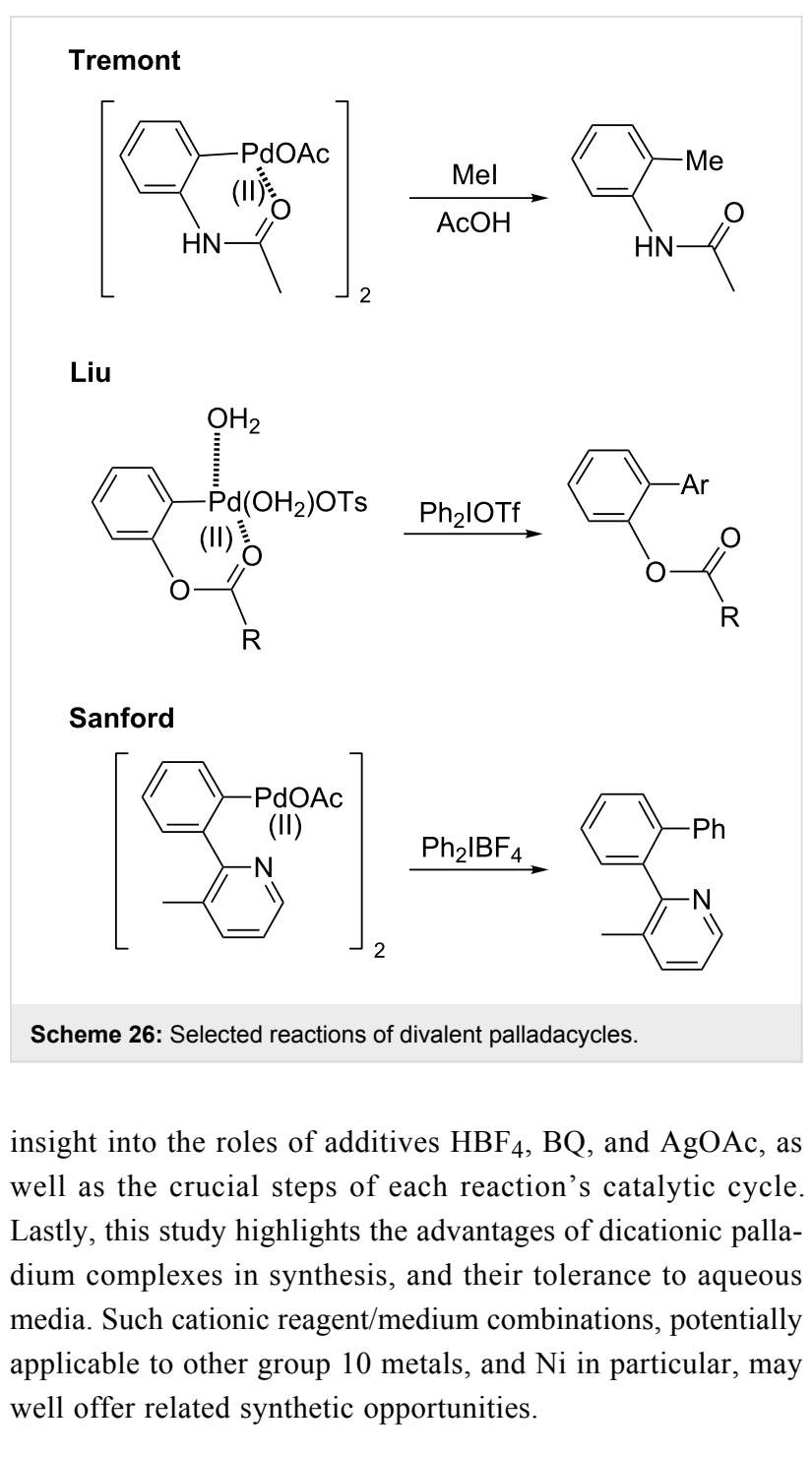

\section{Supporting Information}

\section{Supporting Information File 1}

Experimental procedures and characterization of all new compounds.

[http://www.beilstein-journals.org/bjoc/content/ supplementary/1860-5397-12-99-S1.pdf]

\section{Supporting Information File 2}

Crystal structure of 6 .

[http://www.beilstein-journals.org/bjoc/content/ supplementary/1860-5397-12-99-S2.cif]

\section{Supporting Information File 3}

Crystal structure of 6 No 2.

[http://www.beilstein-journals.org/bjoc/content/ supplementary/1860-5397-12-99-S3.pdf] 


\section{Acknowledgements}

We warmly thank the NIH for support of this work (GM 86485), and Johnson Matthey (Dr. Thomas Colacot) for supplying the $\mathrm{Pd}(\mathrm{OAc})_{2}$ used in this work.

\section{References}

1. Godula, K.; Sames, D. Science 2006, 312, 67-72. doi:10.1126/science.1114731

2. Deprez, N. R.; Sanford, M. S. Inorg. Chem. 2007, 46, 1924-1935. doi:10.1021/ic0620337

3. Alberico, D.; Scott, M. E.; Lautens, M. Chem. Rev. 2007, 107, 174-238. doi:10.1021/cr0509760

4. Park, Y. J.; Park, J.-W.; Jun, C.-H. Acc. Chem. Res. 2008, 41, 222-234. doi:10.1021/ar700133y

5. Kakiuchi, F.; Kochi, T. Synthesis 2008, 3013-3039. doi:10.1055/s-2008-1067256

6. Thansandote, P.; Lautens, M. Chem. - Eur. J. 2009, 15, 5874-5883. doi:10.1002/chem.200900281

7. Chen, X.; Engle, K. M.; Wang, D.-H.; Yu, J.-Q. Angew. Chem., Int. Ed. 2009, 48, 5094-5115. doi:10.1002/anie.200806273

8. Daugulis, O.; Do, H.-Q.; Shabashov, D. Acc. Chem. Res. 2009, 42, 1074-1086. doi:10.1021/ar9000058

9. Giri, R.; Shi, B.-F.; Engle, K. M.; Maugel, N.; Yu, J.-Q. Chem. Soc. Rev. 2009, 38, 3242-3272. doi:10.1039/b816707a

10. Storr, T. E.; Baumann, C. G.; Thatcher, R. J.; De Ornellas, S.; Whitwood, A. C.; Fairlamb, I. J. S. J. Org. Chem. 2009, 74, 5810-5821. doi:10.1021/jo9012282

11. Zhang, M. Adv. Synth. Catal. 2009, 351, 2243-2270. doi:10.1002/adsc. 200900426

12. Vedernikov, A. N. Chem. Commun. 2009, 4781-4790. doi:10.1039/b907036b

13. Muñiz, K. Angew. Chem., Int. Ed. 2009, 48, 9412-9423. doi:10.1002/anie.200903671

14. Colby, D. A.; Bergman, R. G.; Ellman, J. A. Chem. Rev. 2010, 110, 624-655. doi:10.1021/cr900005n

15. Bellina, F.; Rossi, R. Chem. Rev. 2010, 110, 1082-1146. doi:10.1021/cr9000836

16. Scheuermann, C. J. Chem. - Asian J. 2010, 5, 436-451. doi:10.1002/asia.200900487

17. Mkhalid, I. A. I.; Barnard, J. H.; Marder, T. B.; Murphy, J. M.; Hartwig, J. F. Chem. Rev. 2010, 110, 890-931. doi:10.1021/cr900206p

18. Lyons, T. W.; Sanford, M. S. Chem. Rev. 2010, 110, 1147-1169. doi:10.1021/cr900184e

19. Jazzar, R.; Hitce, J.; Renaudat, A.; Sofack-Kreutzer, J.; Baudoin, O. Chem. - Eur. J. 2010, 16, 2654-2672. doi:10.1002/chem.200902374

20. Mousseau, J. J.; Charette, A. B. Acc. Chem. Res. 2013, 46, 412-424. doi:10.1021/ar300185z

21. Neufeldt, S. R.; Sanford, M. S. Acc. Chem. Res. 2012, 45, 936-946. doi:10.1021/ar300014f

22. Guo, X.-X.; Gu, D.-W.; Wu, Z.; Zhang, W. Chem. Rev. 2015, 115, 1622-1651. doi:10.1021/cr500410y

23. Aihara, Y.; Chatani, N. J. Am. Chem. Soc. 2014, 136, 898-901. doi:10.1021/ja411715v

24. Rouquet, G.; Chatani, N. Angew. Chem., Int. Ed. 2013, 52, 11726-11743. doi:10.1002/anie.201301451

25. Chan, K. S. L.; Wasa, M.; Chu, L.; Laforteza, B. N.; Miura, M.; Yu, J.-Q. Nat. Chem. 2014, 6, 146-150. doi:10.1038/nchem.1836
26. Thuy-Boun, P. S.; Villa, G.; Dang, D.; Richardson, P.; Su, S.; Yu, J.-Q. J. Am. Chem. Soc. 2013, 135, 17508-17513. doi:10.1021/ja409014v

27. Lewis, J. C.; Bergman, R. G.; Ellman, J. A. J. Am. Chem. Soc. 2007, 129, 5332-5333. doi:10.1021/ja070388z

28. Tan, K. L.; Bergman, R. G.; Ellman, J. A. J. Am. Chem. Soc. 2002, 124, 3202-3203. doi:10.1021/ja017351d

29. Tan, K. L.; Bergman, R. G.; Ellman, J. A. J. Am. Chem. Soc. 2002, 124, 13964-13965. doi:10.1021/ja0281129

30. Kakiuchi, F.; Sonoda, M.; Tsujimoto, T.; Chatani, N.; Murai, S Chem. Lett. 1999, 28, 1083-1088. doi:10.1246/cl.1999.1083

31. Cook, A. K.; Emmert, M. H.; Sanford, M. S. Org. Lett. 2013, 15, 5428-5431. doi:10.1021/ol4024248

32. Cheng, X.-F.; Li, Y.; Su, Y.-M.; Yin, F.; Wang, J.-Y.; Sheng, J.; Vora, H. U.; Wang, X.-S.; Yu, J.-Q. J. Am. Chem. Soc. 2013, 135, 1236-1239. doi:10.1021/ja311259x

33. Desai, L. V.; Malik, H. A.; Sanford, M. S. Org. Lett. 2006, 8, 1141-1144. doi:10.1021/ol0530272

34. Desai, L. V.; Stowers, K. J.; Sanford, M. S. J. Am. Chem. Soc. 2008, 130, 13285-13293. doi:10.1021/ja8045519

35. Kim, H.; Shin, K.; Chang, S. J. Am. Chem. Soc. 2014, 136, 5904-5907. doi:10.1021/ja502270y

36. Foo, K.; Sella, E.; Thomé, I.; Eastgate, M. D.; Baran, P. S. J. Am. Chem. Soc. 2014, 136, 5279-5282. doi:10.1021/ja501879c

37. Matsubara, T.; Asako, S.; Ilies, L.; Nakamura, E. J. Am. Chem. Soc. 2014, 136, 646-649. doi:10.1021/ja412521k

38. Xiao, B.; Gong, T.-J.; Xu, J.; Liu, Z.-J.; Liu, L. J. Am. Chem. Soc. 2011, 133, 1466-1474. doi:10.1021/ja108450m

39. Sun, K.; Li, Y.; Xiong, T.; Zhang, J.; Zhang, Q. J. Am. Chem. Soc. 2011, 133, 1694-1697. doi:10.1021/ja1101695

40. Kawano, T.; Hirano, K.; Satoh, T.; Miura, M. J. Am. Chem. Soc. 2010, 132, 6900-6901. doi:10.1021/ja101939r

41. Houlden, C. E.; Bailey, C. D.; Ford, J. G.; Gagné, M. R.; Lloyd-Jones, G. C.; Booker-Milburn, K. I. J. Am. Chem. Soc. 2008, 130, 10066-10067. doi:10.1021/ja803397y

42. Dick, A. R.; Remy, M. S.; Kampf, J. W.; Sanford, M. S. Organometallics 2007, 26, 1365-1370. doi:10.1021/om061052।

43. He, J.; Wasa, M.; Chan, K. S. L.; Yu, J.-Q. J. Am. Chem. Soc. 2013, 135, 3387-3390. doi:10.1021/ja400648w

44. Tobisu, M.; Ano, Y.; Chatani, N. Org. Lett. 2009, 11, 3250-3252. doi:10.1021/ol901049r

45. Vora, H. U.; Silvestri, A. P.; Engelin, C. J.; Yu, J.-Q. Angew. Chem., Int. Ed. 2014, 53, 2683-2686. doi:10.1002/anie.201310539

46. García-Rubia, A.; Urones, B.; Arrayás, R. G.; Carretero, J. C. Angew. Chem., Int. Ed. 2011, 50, 10927-10931. doi:10.1002/anie.201105611

47. Nakao, Y.; Yada, A.; Ebata, S.; Hiyama, T. J. Am. Chem. Soc. 2007, 129, 2428-2429. doi:10.1021/ja067364x

48. Satoh, T.; Nishinaka, Y.; Miura, M.; Nomura, M. Chem. Lett. 1999, 28, 615-618. doi:10.1246/cl.1999.615

49. Ueura, K.; Satoh, T.; Miura, M. Org. Lett. 2007, 9, 1407-1409. doi:10.1021/ol070406h

50. Lee, G. T.; Jiang, X.; Prasad, K.; Repič, O.; Blacklock, T. J. Adv. Synth. Catal. 2005, 347, 1921-1924. doi:10.1002/adsc.200505202

51. Lim, S.-G.; Lee, J. H.; Moon, C. W.; Hong, J.-B.; Jun, C.-H. Org. Lett. 2003, 5, 2759-2761. doi:10.1021/ol035083d

52. Furukawa, T.; Tobisu, M.; Chatani, N. J. Am. Chem. Soc. 2015, 137, 12211-12214. doi:10.1021/jacs.5b07677 
53. Cho, S. H.; Hartwig, J. F. J. Am. Chem. Soc. 2013, 135, 8157-8160. doi:10.1021/ja403462b

54. Kawamorita, S.; Murakami, R.; Iwai, T.; Sawamura, M. J. Am. Chem. Soc. 2013, 135, 2947-2950. doi:10.1021/ja3126239

55. Kawamorita, S.; Ohmiya, H.; Hara, K.; Fukuoka, A.; Sawamura, M. J. Am. Chem. Soc. 2009, 131, 5058-5059. doi:10.1021/ja9008419

56. Boebel, T. A.; Hartwig, J. F. J. Am. Chem. Soc. 2008, 130, 7534-7535. doi:10.1021/ja8015878

57. Boller, T. M.; Murphy, J. M.; Hapke, M.; Ishiyama, T.; Miyaura, N.; Hartwig, J. F. J. Am. Chem. Soc. 2005, 127, 14263-14278. doi:10.1021/ja053433g

58. Ishiyama, T.; Takagi, J.; Ishida, K.; Miyaura, N.; Anastasi, N. R.; Hartwig, J. F. J. Am. Chem. Soc. 2002, 124, 390-391. doi:10.1021/ja0173019

59. Chen, H.; Schlecht, S.; Semple, T. C.; Hartwig, J. F. Science 2000, 287, 1995. doi:10.1126/science.287.5460.1995

60. Cho, J.-Y.; Iverson, C. N.; Smith, M. R., III. J. Am. Chem. Soc. 2000 , 122, 12868-12869. doi:10.1021/ja0013069

61. Tse, M. K.; Cho, J.-Y.; Smith, M. R., III. Org. Lett. 2001, 3 , 2831-2833. doi:10.1021/ol0162668

62. Zhao, X.; Dimitrijević, E.; Dong, V. M. J. Am. Chem. Soc. 2009, 131, 3466-3467. doi:10.1021/ja900200g

63. Yu, W.-Y.; Sit, W. N.; Lai, K.-M.; Zhou, Z.; Chan, A. S. C. J. Am. Chem. Soc. 2008, 130, 3304-3306. doi:10.1021/ja710555g

64. Chu, L.; Wang, X.-C.; Moore, C. E.; Rheingold, A. L.; Yu, J.-Q. J. Am. Chem. Soc. 2013, 135, 16344-16347. doi:10.1021/ja408864c

65. Wang, X.; Mei, T.-S.; Yu, J.-Q. J. Am. Chem. Soc. 2009, 131, 7520-7521. doi:10.1021/ja901352k

66. Li, J.-J.; Mei, T.-S.; Yu, J.-Q. Angew. Chem., Int. Ed. 2008, 47, 6452-6455. doi:10.1002/anie.200802187

67. Whitfield, S. R.; Sanford, M. S. J. Am. Chem. Soc. 2007, 129, 15142-15143. doi:10.1021/ja077866q

68. Hull, K. L.; Anani, W. Q.; Sanford, M. S. J. Am. Chem. Soc. 2006, 128, 7134-7135. doi:10.1021/ja061943k

69. Powers, D. C.; Ritter, T. Nat. Chem. 2009, 1, 302-309. doi:10.1038/nchem.246

70. Jia, X.; Zhang, S.; Wang, W.; Luo, F.; Cheng, J. Org. Lett. 2009, 11, 3120-3123. doi:10.1021/ol900934g

71. Ma, S.; Villa, G.; Thuy-Boun, P. S.; Homs, A.; Yu, J.-Q. Angew. Chem., Int. Ed. 2014, 53, 734-737. doi:10.1002/anie.201305388

72. Hesp, K. D.; Bergman, R. G.; Ellman, J. A. J. Am. Chem. Soc. 2011, 133, 11430-11433. doi:10.1021/ja203495c

73. Xiao, B.; Fu, Y.; Xu, J.; Gong, T.-J.; Dai, J.-J.; Yi, J.; Liu, L. J. Am. Chem. Soc. 2010, 132, 468-469. doi:10.1021/ja909818n

74. Brand, J. P.; Charpentier, J.; Waser, J. Angew. Chem., Int. Ed. 2009, 48, 9346-9349. doi:10.1002/anie.200905419

75. Boele, M. D. K.; van Strijdonck, G. P. F.; de Vries, A. H. M.; Kamer, P. C. J.; de Vries, J. G.; van Leeuwen, P. W. N. M. J. Am. Chem. Soc. 2002, 124, 1586-1587. doi:10.1021/ja0176907

76. Ishiyama, T.; Takagi, J.; Hartwig, J. F.; Miyaura, N. Angew. Chem., Int. Ed. 2002, 41, 3056-3058. doi:10.1002/1521-3773(20020816)41:16<3056::AID-ANIE3056>3.0.C O;2-\#

77. Campeau, L.-C.; Bertrand-Laperle, M.; Leclerc, J.-P.; Villemure, E.; Gorelsky, S.; Fagnou, K. J. Am. Chem. Soc. 2008, 130, 3276-3277. doi:10.1021/ja7107068

78. Chary, B. C.; Kim, S.; Park, Y.; Kim, J.; Lee, P. H. Org. Lett. 2013, 15 2692-2695. doi:10.1021/ol4009987
79. Yang, F.; Song, F.; Li, W.; Lan, J.; You, J. RSC Adv. 2013, 3, 9649-9652. doi:10.1039/c3ra41981a

80. Kakiuchi, F.; Murai, S. Org. Synth. 2003, 80, 104-110. doi:10.15227/orgsyn.080.0104

81. Sonoda, M.; Kakiuchi, F.; Chatani, N.; Murai, S. Bull. Chem. Soc. Jpn. 1997, 70, 3117-3128. doi:10.1246/bcsj.70.3117

82. Kakiuchi, F.; Sekine, S.; Tanaka, Y.; Kamatani, A.; Sonoda, M.; Chatani, N.; Murai, S. Bull. Chem. Soc. Jpn. 1995, 68, 62-83. doi:10.1246/bcsj.68.62

83. Sonoda, M.; Kakiuchi, F.; Chatani, N.; Murai, S. J. Organomet. Chem. 1995, 504, 151-152. doi:10.1016/0022-328X(95)05607-Q

84. Murai, S.; Kakiuchi, F.; Sekine, S.; Tanaka, Y.; Kamatani, A.; Sonoda, M.; Chatani, N. Pure Appl. Chem. 1994, 66, 1527-1534. doi:10.1351/pac199466071527

85. Murai, S.; Kakiuchi, F.; Sekine, S.; Tanaka, Y.; Kamatani, A.; Sonoda, M.; Chatani, N. Nature 1993, 366, 529-531. doi:10.1038/366529a0

86. Yang, S.; Li, B.; Wan, X.; Shi, Z. J. Am. Chem. Soc. 2007, 129, 6066-6067. doi:10.1021/ja070767s

87. Li, B.-J.; Tian, S.-L.; Fang, Z.; Shi, Z.-J. Angew. Chem., Int. Ed. 2008, 47, 1115-1118. doi:10.1002/anie.200704092

88. Ackermann, L.; Vicente, R.; Althammer, A. Org. Lett. 2008, 10, 2299-2302. doi:10.1021/ol800773x

89. Kakiuchi, F.; Sato, T.; Yamauchi, M.; Chatani, N.; Murai, S. Chem. Lett. 1999, 28, 19-20. doi:10.1246/cl.1999.19

90. Desai, L. V.; Hull, K. L.; Sanford, M. S. J. Am. Chem. Soc. 2004, 126, 9542-9543. doi:10.1021/ja046831c

91. Thu, H.-Y.; Yu, W.-Y.; Che, C.-M. J. Am. Chem. Soc. 2006, 128, 9048-9049. doi:10.1021/ja062856v

92. Campeau, L.-C.; Schipper, D. J.; Fagnou, K. J. Am. Chem. Soc. 2008, 130, 3266-3267. doi:10.1021/ja710451s

93. Lazareva, A.; Daugulis, O. Org. Lett. 2006, 8, 5211-5213. doi:10.1021/ol061919b

94. Cai, G.; Fu, Y.; Li, Y.; Wan, X.; Shi, Z. J. Am. Chem. Soc. 2007, 129, 7666-7673. doi:10.1021/ja070588a

95. Kuninobu, Y.; Ida, H.; Nishi, M.; Kanai, M. Nat. Chem. 2015, 7, 712-717. doi:10.1038/nchem.2322

96. He, J.; Li, S.; Deng, Y.; Fu, H.; Laforteza, B. N.; Spangler, J. E.; Homs, A.; Yu, J.-Q. Science 2014, 343, 1216-1220. doi:10.1126/science.1249198

97. Iwai, T.; Harada, T.; Hara, K.; Sawamura, M. Angew. Chem., Int. Ed. 2013, 52, 12322-12326. doi:10.1002/anie.201306769

98. Ishiyama, T.; Isou, H.; Kikuchi, T.; Miyaura, N. Chem. Commun. 2010, 46, 159-161. doi:10.1039/B910298A

99. Wang, D.-H.; Engle, K. M.; Shi, B.-F.; Yu, J.-Q. Science 2010, 327, 315-319. doi:10.1126/science.1182512

100.Stang, E. M.; White, M. C. Nat. Chem. 2009, 1, 547-551. doi:10.1038/nchem.351

101. Lafrance, M.; Lopointe, D.; Fagnou, K. Tetrahedron 2008, 64, 6015-6020. doi:10.1016/j.tet.2008.01.057

102. Reed, S. A.; White, M. C. J. Am. Chem. Soc. 2008, 130, 3316-3318. doi:10.1021/ja710206u

103.Ackermann, L.; Althammer, A.; Born, R. Angew. Chem., Int. Ed. 2006, 45, 2619-2622. doi:10.1002/anie.200504450

104.Saiki, T.; Nishio, Y.; Ishiyama, T.; Miyaura, N. Organometallics 2006, 25, 6068-6073. doi:10.1021/om050968+

105. Chen, M. S.; Prabagaran, N.; Labenz, N. A.; White, M. C. J. Am. Chem. Soc. 2005, 127, 6970-6971. doi:10.1021/ja0500198

106. Tsukada, N.; Mitsuboshi, T.; Setoguchi, H.; Inoue, Y. J. Am. Chem. Soc. 2003, 125, 12102-12103. doi:10.1021/ja0375075 
107.Gray, J. B.; Cook, A. K.; Sanford, M. S. ACS Catal. 2013, 3, 700-703. doi:10.1021/cs300786j

108.Balcells, D.; Clot, E.; Eisenstein, O. Chem. Rev. 2010, 110, 749-823. doi:10.1021/cr900315k

109.Powers, D. C.; Geibel, M. A. L.; Klein, J. E. M. N.; Ritter, T. J. Am. Chem. Soc. 2009, 131, 17050-17051. doi:10.1021/ja906935c

110. Hull, K. L.; Sanford, M. S. J. Am. Chem. Soc. 2009, 131, 9651-9653. doi:10.1021/ja901952h

111. García-Cuadrado, D.; de Mendoza, P.; Braga, A. A. C.; Maseras, F.; Echavarren, A. M. J. Am. Chem. Soc. 2007, 129, 6880-6886. doi:10.1021/ja071034a

112.Lafrance, M.; Fagnou, K. J. Am. Chem. Soc. 2006, 128, 16496-16497. doi:10.1021/ja067144j

113. Campeau, L.-C.; Fagnou, K. Chem. Commun. 2006, 1253-1264. doi:10.1039/b515481m

114.García-Cuadrado, D.; Braga, A. A. C.; Maseras, F.; Echavarren, A. M. J. Am. Chem. Soc. 2006, 128, 1066-1067. doi:10.1021/ja056165v

115.Davies, D. L.; Donald, S. M. A.; Macgregor, S. A. J. Am. Chem. Soc. 2005, 127, 13754-13755. doi:10.1021/ja052047w

116. Maleckis, A.; Kampf, J. W.; Sanford, M. S. J. Am. Chem. Soc. 2013, 135, 6618-6625. doi:10.1021/ja401557m

117.Dick, A. R.; Kampf, J. W.; Sanford, M. S. J. Am. Chem. Soc. 2005, 127, 12790-12791. doi:10.1021/ja0541940

118. Biswas, B.; Sugimoto, M.; Sakaki, S. Organometallics 2000, 19 , 3895-3908. doi:10.1021/om000002s

119. Horino, H.; Inoue, N. J. Org. Chem. 1981, 46, 4416-4422. doi:10.1021/jo00335a019

120.Zudin, V. N.; Chinakov, V. D.; Nekipelov, V. M.; Rogov, V. A.; Likholobov, V. A.; Yermakov, Yu. I. J. Mol. Catal. 1989, 52, 27-48. doi:10.1016/0304-5102(89)80080-X

121. Nishikata, T.; Abela, A. R.; Lipshutz, B. H. Angew. Chem., Int. Ed. 2010, 49, 781-784. doi:10.1002/anie.200905967

122. Nishikata, T.; Abela, A. R.; Huang, S.; Lipshutz, B. H. J. Am. Chem. Soc. 2010, 132, 4978-4979. doi:10.1021/ja910973a

123. Yamamoto, A. J. Organomet. Chem. 1995, 500, 337-348. doi:10.1016/0022-328X(95)00521-Q

124. Oi, S.; Kashiwagi, K.; Inoue, Y. Tetrahedron Lett. 1998, 39, 6253-6256. doi:10.1016/S0040-4039(98)01288-X

125. Oi, S.; Kashiwagi, K.; Terada, E.; Ohuchi, K.; Inoue, Y. Tetrahedron Lett. 1996, 37, 6351-6354. doi:10.1016/0040-4039(96)01369-X

126.Sodeoka, M.; Hamashima, Y. Chem. Commun. 2009, 5787-5798. doi:10.1039/b911015a

127.Sodeoka, M.; Hamashima, Y. Bull. Chem. Soc. Jpn. 2005, 78, 941-956. doi:10.1246/bcsj.78.941

128. Fujii, A.; Hagiwara, E.; Sodeoka, M. J. Am. Chem. Soc. 1999, 121 , 5450-5458. doi:10.1021/ja9902827

129. Gaunt, M. J.; Spencer, J. B. Org. Lett. 2001, 3, 25-28. doi:10.1021/ol0066882

130. Chen, C.; Luo, S.; Jordan, R. F. J. Am. Chem. Soc. 2010, 132, 5273-5284. doi:10.1021/ja100491y

131.Brookhart, M.; Wagner, M. I.; Balavoine, G. G. A.; Haddou, H. A. J. Am. Chem. Soc. 1994, 116, 3641-3642. doi:10.1021/ja00087a077

132. Yamamoto, Y.; Nishikata, T.; Miyaura, N. Pure Appl. Chem. 2008, 80 , 807-817. doi:10.1351/pac200880050807

133. Miyaura, N. Synlett 2009, 2039-2042. doi:10.1055/s-0029-1217555

134. Nishikata, T.; Yamamoto, Y.; Miyaura, N. Angew. Chem., Int. Ed. 2003, 42, 2768-2770. doi:10.1002/anie.200350888

135. Nishikata, T.; Yamamoto, Y.; Miyaura, N. Chem. Commun. 2004, 1822-1823. doi:10.1039/b407272c
136. Nishikata, T.; Yamamoto, Y.; Miyaura, N. Chem. Lett. 2003, 32, 752-753. doi:10.1246/cl.2003.752

137.Lebrasseur, N.; Larrosa, I. J. Am. Chem. Soc. 2008, 130, 2926-2927. doi:10.1021/ja710731a

138. Stuart, D. R.; Fagnou, K. Science 2007, 316, 1172-1175. doi:10.1126/science.1141956

139.Deprez, N. R.; Kalyani, D.; Krause, A.; Sanford, M. S. J. Am. Chem. Soc. 2006, 128, 4972-4973. doi:10.1021/ja060809x

140. Hughes, C. C.; Trauner, D. Angew. Chem., Int. Ed. 2002, 41, 1569-1572. doi:10.1002/1521-3773(20020503)41:9<1569::AID-ANIE1569>3.0.CO ;2-8

141.Jia, C.; Piao, D.; Oyamada, J.; Lu, W.; Kitamura, T.; Fujiwara, Y. Science 2000, 287, 1992-1995. doi:10.1126/science.287.5460.1992

142.Pivsa-Art, S.; Satoh, T.; Kawamura, Y.; Miura, M.; Nomura, M. Bull. Chem. Soc. Jpn. 1998, 71, 467-473. doi:10.1246/bcsj.71.467

143. Albano, V. G.; Di Serio, M.; Monari, M.; Orabona, I.; Panunzi, A.; Ruffo, F. Inorg. Chem. 2002, 41, 2672-2677. doi:10.1021/ic011059p

144. Liston, D. J.; Lee, Y. J.; Scheidt, W. R.; Reed, C. A.

J. Am. Chem. Soc. 1989, 111, 6643-6648. doi:10.1021/ja00199a025

145.Davis, J. A.; Hartley, E. R.; Muray, S. G. J. Chem. Soc., Dalton Trans. 1980, 2246-2249. doi:10.1039/dt9800002246

146. Amatore, C.; Jutand, A.; Mederious, M. J.; Mottier, L. J. Electroanal. Chem. 1997, 422, 125-132. doi:10.1016/S0022-0728(96)04901-7

147. Grushin, V. V. Chem. Rev. 1996, 96, 2011-2034. doi:10.1021/cr950272y

148. Nishikata, T.; Lipshutz, B. H. Org. Lett. 2010, 12, 1972-1975. doi:10.1021/ol100331h

149. Ricci, P.; Krämer, K.; Cambeiro, X. C.; Larrosa, I. J. Am. Chem. Soc. 2013, 135, 13258-13261. doi:10.1021/ja405936s

150. Join, B.; Yamamoto, T.; Itami, K. Angew. Chem., Int. Ed. 2009, 48, 3644-3647. doi:10.1002/anie.200806358

151.Campeau, L.-C.; Stuart, D. R.; Leclerc, J.-P.; Bertrand-Laperle, M.; Villemure, E.; Sun, H.-Y.; Lasserre, S.; Guimond, N.; Lecavallier, M.; Fagnou, K. J. Am. Chem. Soc. 2009, 131, 3291-3306. doi:10.1021/ja808332k

152. Yang, F.; Wu, Y.; Li, Y.; Wang, B.; Zhang, J. Tetrahedron 2009, 65, 914-919. doi:10.1016/j.tet.2008.11.001

153.Scarborough, C. C.; McDonald, R. I.; Hartmann, C.; Sazama, G. T.; Bergant, A.; Stahl, S. S. J. Org. Chem. 2009, 74, 2613-2615. doi:10.1021/j0802632v

154.Kim, J.; Jo, M.; So, W.; No, Z. Tetrahedron Lett. 2009, 50, 1229-1362. doi:10.1016/j.tetlet.2009.01.010

155. Gorelsky, S. I.; Lapointe, D.; Fagnou, K. J. Am. Chem. Soc. 2008, 130, 10848-10849. doi:10.1021/ja802533u

156.Li, D.-D.; Yuan, T.-T.; Wang, G.-W. J. Org. Chem. 2012, 77, 3341-3347. doi:10.1021/jo300126n

157.Chen, F.; Min, Q.-Q.; Zhang, X. J. Org. Chem. 2012, 77, 2992-2998. doi:10.1021/jo300036d

158.Liang, Z.; Feng, R.; Yin, H.; Zhang, Y. Org. Lett. 2013, 15, 4544-4547. doi:10.1021/ol402207g

159.Shi, B.-S.; Zhang, Y.-H.; Lam, J. K.; Wang, D.-H.; Yu, J.-Q. J. Am. Chem. Soc. 2010, 132, 460-461. doi:10.1021/ja909571z

160. Chu, J.-H.; Tsai, S.-L.; Wu, M.-J. Synthesis 2009, 3757-3764. doi:10.1055/s-0029-1217014

161.Shi, B.-F.; Maugel, N.; Zhang, Y.-H.; Yu, J.-Q. Angew. Chem., Int. Ed. 2008, 47, 4882-4886. doi:10.1002/anie.200801030

162.Wang, D.-H.; Wasa, M.; Giri, R.; Yu, J.-Q. J. Am. Chem. Soc. 2008, 130, 7190-7191. doi:10.1021/ja801355s 
163.Wang, D.-H.; Mei, T.-S.; Yu, J.-Q. J. Am. Chem. Soc. 2008, 130, 17676-17677. doi:10.1021/ja806681z

164. Kirchberg, S.; Vogler, T.; Studer, A. Synlett 2008, 2841-2845. doi:10.1055/s-0028-1083546

165. Vogler, T.; Studer, A. Org. Lett. 2008, 10, 129-131. doi:10.1021/ol702659a

166.Giri, R.; Maugel, N.; Li, J.-J.; Wang, D.-H.; Breazzano, S. P.; Saunders, L. B.; Yu, J.-Q. J. Am. Chem. Soc. 2007, 129, 3510-3511. doi:10.1021/ja0701614

167.Chen, X.; Goodhue, C. E.; Yu, J.-Q. J. Am. Chem. Soc. 2006, 128, 12634-12635. doi:10.1021/ja0646747

168.Kakiuchi, F.; Kan, S.; Igi, K.; Chatani, N.; Murai, S. J. Am. Chem. Soc. 2003, 125, 1698-1699. doi:10.1021/ja029273f

169.Liang, Z.; Yao, J.; Wang, K.; Li, H.; Zhang, Y. Chem. - Eur. J. 2013, 19, 16825-16831. doi:10.1002/chem.201301229

170.Meng, X.; Kim, S. J. Org. Chem. 2013, 78, 11247-11251. doi:10.1021/jo401716p

171.Yamaguchi, K.; Kondo, H.; Yamaguchi, J.; Itami, K. Chem. Sci. 2013, 4, 3753-3757. doi:10.1039/c3sc51206a

172. Tremont, S. J.; Ur Rahman, H. J. Am. Chem. Soc. 1984, 106, 5759-5760. doi:10.1021/ja00331a073

173.Shabashov, D.; Daugulis, O. J. Org. Chem. 2007, 72, 7720-7725. doi:10.1021/jo701387m

174.Daugulis, O.; Zaitsev, V. G. Angew. Chem., Int. Ed. 2005, 44, 4046-4048. doi:10.1002/anie.200500589

175.Kalyani, D.; Deprez, N. R.; Desai, L. V.; Sanford, M. S. J. Am. Chem. Soc. 2005, 127, 7330-7331. doi:10.1021/ja051402f

176. Houlden, C. E.; Hutchby, M.; Bailey, C. D.; Ford, J. G.; Tyler, S. N. G.; Gagné, M. R.; Lloyd-Jones, G. C.; Booker-Milburn, K. I. Angew. Chem., Int. Ed. 2009, 48, 1830-1833. doi:10.1002/anie.200805842

177. Nishikata, T.; Lipshutz, B. H. J. Am. Chem. Soc. 2009, 131, 12103-12105. doi:10.1021/ja905082c

178. Nishikata, T.; Lipshutz, B. H. Org. Lett. 2009, 11, 2377-2379. doi:10.1021/ol900235s

179. Lipshutz, B. H.; Ghorai, S. Aldrichimica Acta 2008, 41, 58-72.

180. Ohnmacht, S. A.; Mamone, P.; Culshaw, A. J.; Greaney, M. F. Chem. Commun. 2008, 1241-1243. doi:10.1039/b719466h

181.Flegeau, E. F.; Popkin, M. E.; Greaney, M. F. Org. Lett. 2008, 10 , 2717-2720. doi:10.1021/ol800869g

182. Turner, G. L.; Morris, J. A.; Greaney, M. F. Angew. Chem., Int. Ed. 2007, 46, 7996-8000. doi:10.1002/anie.200702141

183. Herrerías, C. I.; Yao, X.; Li, Z.; Li, C.-J. Chem. Rev. 2007, 107, 2546-2562. doi:10.1021/cr050980b

184. Mitsudo, K.; Kaide, T.; Nakamoto, E.; Yoshida, K.; Tanaka, H. J. Am. Chem. Soc. 2007, 129, 2246-2247. doi:10.1021/ja069043r

185. Oi, S.; Aizawa, E.; Ogino, Y.; Inoue, Y. J. Org. Chem. 2005, 70, 3113-3119. doi:10.1021/jo050031i

186. Bedford, R. B.; Limmert, M. E. J. Org. Chem. 2003, 68, 8669-8682. doi:10.1021/jo030157k

187. Oi, S.; Watanabe, S.-i.; Fukita, S.; Inoue, Y. Tetrahedron Lett. 2003, 44, 8665-8668. doi:10.1016/j.tetlet.2003.09.151

188. Oi, S.; Fukita, S.; Hirata, N.; Watanuki, N.; Miyano, S.; Inoue, Y. Org. Lett. 2001, 3, 2579-2581. doi:10.1021/ol016257z

189. Oi, S.; Fukita, S.; Inoue, Y. Chem. Commun. 1998, 2439-2440. doi:10.1039/a806790b

190. Fujiwara, Y.; Moritani, I.; Danno, S.; Asano, R.; Teranishi, S. J. Am. Chem. Soc. 1969, 91, 7166-7169. doi:10.1021/ja01053a047

191.Fujiwara, Y.; Moritani, I.; Matsuda, M.; Teranishi, S. Tetrahedron Lett. 1968, 9, 633-636. doi:10.1016/S0040-4039(01)98820-3
192. Moritani, S.; Fujiwara, Y. Tetrahedron Lett. 1967, 8, 1119-1122. doi:10.1016/S0040-4039(00)90648-8

193. Jiao, L.-Y.; Oestreich, M. Org. Lett. 2013, 15, 5374-5377. doi:10.1021/ol402687t

194.Wang, L.; Liu, S.; Li, Z.; Yu, Y. Org. Lett. 2011, 13, 6137-6139. doi:10.1021/ol202738j

195. Rauf, W.; Thompson, A. L.; Brown, J. M. Dalton Trans. 2010, 39, 10414-10421. doi:10.1039/c0dt00378f

196.Wu, J.; Cui, X.; Chen, L.; Jiang, G.; Wu, Y. J. Am. Chem. Soc. 2009, 131, 13888-13889. doi:10.1021/ja902762a

197.Aouf, C.; Thiery, E.; Le Bras, J.; Muzart, J. Org. Lett. 2009, 11, 4096-4099. doi:10.1021/ol901570p

198. Cheng, D.; Gallagher, T. Org. Lett. 2009, 11, 2639-2641. doi:10.1021/ol900627q

199. Cho, S. H.; Hwang, S. J.; Chang, S. J. Am. Chem. Soc. 2008, 130 , 9254-9256. doi:10.1021/ja8026295

200.Dams, M.; De Vos, D. E.; Celen, S.; Jacobs, P. A. Angew. Chem., Int. Ed. 2003, 42, 3512-3515. doi:10.1002/anie.200351524

201. Yokota, T.; Tani, M.; Sakaguchi, S.; Ishii, Y. J. Am. Chem. Soc. 2003, 125, 1476-1477. doi:10.1021/ja028903a

202. Weissman, H.; Song, X.; Milstein, D. J. Am. Chem. Soc. 2001, 123, 337-338. doi:10.1021/ja003361n

203.Meng, X.; Kim, S. Org. Lett. 2013, 15, 1910-1913. doi:10.1021/ol400565r

204.Dai, H.-X.; Li, G.; Zhang, X.-G.; Stephan, A. F.; Yu, J.-Q. J. Am. Chem. Soc. 2013, 135, 7567-7571. doi:10.1021/ja400659s

205.Zhang, Y.-H.; Shi, B.-F.; Yu, J.-Q. J. Am. Chem. Soc. 2009, 131, 5072-5074. doi:10.1021/ja900327e

206. Rauf, W.; Thompson, A. L.; Brown, J. M. Chem. Commun. 2009, 3874-3876. doi:10.1039/b905717j

207. Rouhi, A. M. Chem. Eng. News 2004, 82, 49-58.

208. Felpin, F.-X.; Fouquet, E.; Zakri, C. Adv. Synth. Catal. 2009, 351 , 649-650. doi:10.1002/adsc.200800783

209. Wetzel, A.; Ehrhardt, V.; Heinrich, M. R. Angew. Chem., Int. Ed. 2008, 47, 9130-9133. doi:10.1002/anie.200803785

210.Spivey, A. C.; Tseng, C.-C.; Hannah, J. P.; Gripton, C. J. P.; de Fraine, P.; Parr, N. J.; Scicinski, J. J. Chem. Commun. 2007, 2926-2928. doi:10.1039/B707517K

211. Ehrenfreund, J.; Lamberth, C.; Tobler, H.; Walter, H. Biphenyl derivatives and their use as fungicides. WO Patent WO 2004058723, July 15, 2004.

212. Eicken, K.; Rack, M.; Wetterich, F.; Ammermann, E.; Lorenz, G.; Strathmann, S. Biphenylamide. German Patent DE 19735224, Feb 18, 1999.

213. Eicken, K.; Rang, H.; Harreus, A.; Goetz, N.; Ammermann, E.; Lorenz, G.; Strathmann, S. Bisphenylamide. German Patent DE19531813, March 6, 1997.

214. Urriolabeitia, E. P. Oxidative Addition and Transmetallation. In Palladacycles: Synthesis, Characterization and Applications; Dupont, J.; Pfeffer, M., Eds.; Wiley-VCH: Weinheim, Germany, 2008.

215.Roiban, G.-D.; Serrano, E.; Soler, T.; Contel, M.; Grosu, I.; Cativiela, C.; Urriolabeitia, E. P. Organometallics 2010, 29, 1428-1435. doi:10.1021/om901068f

216. The palladacycle is very stable and did not release the corresponding arylurea after 2-3 weeks in wet solvent.

217.Steffen, W. L.; Palenik, G. J. Inorg. Chem. 1976, 15, 2432-2439. doi:10.1021/ic50164a025

218.Ludwig, M.; Strömberg, S.; Svensson, M.; Åkermark, B. Organometallics 1999, 18, 970-975. doi:10.1021/om9803265 
219. Nishikata, T.; Yamamoto, Y.; Gridnev, I. D.; Miyaura, N. Organometallics 2005, 24, 5025-5032. doi:10.1021/om050678t

220. Nishikata, T.; Yamamoto, Y.; Miyaura, N. Organometallics 2004, 23 , 4317-4324. doi:10.1021/om0498044

221.Albrecht, M. Chem. Rev. 2010, 110, 576-623. doi:10.1021/cr900279a

222.Chatani, N., Ed. Directed Metallation; Topics in Organometallic Chemistry, Vol. 24; Springer: Berlin, Germany, 2007.

223. Yu, J.-Q.; Giri, R.; Chen, X. Org. Biomol. Chem. 2006, 4, 4041-4047. doi:10.1039/B611094K

224.Dupont, J.; Consorti, C. S.; Spencer, J. Chem. Rev. 2005, 105, 2527-2572. doi:10.1021/cr030681r

225.Chu, J.-H.; Chen, C.-C.; Wu, M.-J. Organometallics 2008, 27 , 5173-5176. doi:10.1021/om800606c

226.Pérez-Rodríguez, M.; Braga, A. A. C.; Garcia-Melchor, M.; Pérez-Temprano, M. H.; Casares, J. A.; Ujaque, G.; de Lera, A. R.; Alvarez, R.; Maseras, F.; Espinet, P. J. Am. Chem. Soc. 2009, 131, 3650-3657. doi:10.1021/ja808036j

227.Albéniz, A. C.; Espinet, P.; Martín-Ruiz, B. Chem. - Eur. J. 2001, 7, 2481-2485. doi:10.1002/1521-3765(20010601)7:11<2481::AID-CHEM24810>3.0. $\mathrm{CO} ; 2-2$

228.Szabó, K. J. Organometallics 1998, 17, 1677-1686. doi:10.1021/om9800344

229. Bäckvall, J. E.; Byström, S. E.; Nordberg, R. E. J. Org. Chem. 1984, 49, 4619-4631. doi:10.1021/jo00198a010

230. Temple, J. S.; Riediker, M.; Schwartz, J. J. Am. Chem. Soc. 1982, 104, 1310-1315. doi:10.1021/ja00369a028

231.1,4-Dihydroxybenzene was confirmed by ${ }^{1} \mathrm{H}$, and ${ }^{13} \mathrm{C}$ NMR and GC-MS analysis.

232. Some previous $\mathrm{C}-\mathrm{H}$ activation reactions catalyzed by $\mathrm{Pd}(\mathrm{OAc})_{2}$ require high temperature to generate a cationic species. TFA or $p-\mathrm{TsOH}$ led to room temperature $\mathrm{C}-\mathrm{H}$ activation only when catalyzed by $\mathrm{Pd}(\mathrm{OAc})_{2}$ probably due to generation of a cationic $\mathrm{Pd}(\mathrm{II})$ species.

233. Crociani, B.; Di Bianca, F.; Uguagliati, P.; Canovese, L.; Berton, A. J. Chem. Soc., Dalton Trans. 1991, 71-79. doi:10.1039/DT9910000071

234. Eaborn, C.; Odell, K. J.; Pidcock, A. J. Chem. Soc., Dalton Trans. 1978, 357-368. doi:10.1039/DT9780000357

235. Foresee, L. N.; Tunge, J. A. Organometallics 2005, 24, 6440-6444. doi:10.1021/om0507225

236.Jia, C.; Lu, W.; Oyamada, J.; Kitamura, T.; Matsuda, K.; Irie, M.; Fujiwara, Y. J. Am. Chem. Soc. 2000, 122, 7252-7263. doi:10.1021/ja0005845

237. We have not yet obtained strong proof of this species based on either a kinetic or an isotope effect study.

238. Kawataka, F.; Shimizu, I.; Yamamoto, A. Bull. Chem. Soc. Jpn. 1995, 68, 654-660. doi:10.1246/bcsj.68.654

239. Karabelas, K.; Hallberg, A. J. Org. Chem. 1986, 51, 5286-5290. doi:10.1021/jo00376a044

240. Karabelas, K.; Westerlund, C.; Hallberg, A. J. Org. Chem. 1985, 50, 3896-3900. doi:10.1021/jo00220a042

241. Molander, G. A.; Canturk, B. Angew. Chem., Int. Ed. 2009, 48, 9240-9261. doi:10.1002/anie.200904306

242.Martin, R.; Buchwald, S. L. Acc. Chem. Res. 2008, 41, 1461. doi:10.1021/ar800036s

243. Miyaura, N.; Suzuki, A. Chem. Rev. 1995, 95, 2457-2483. doi:10.1021/cr00039a007

244.Sicre, C.; Braga, A. A. C.; Maseras, F.; Magdalena Cid, M. Tetrahedron 2008, 64, 7437-7650. doi:10.1016/j.tet.2008.05.018
245.Braga, A. A. C.; Morgon, N. H.; Ujaque, G.; Maseras, F. J. Am. Chem. Soc. 2005, 127, 9298-9307. doi:10.1021/ja050583i

246. Matos, K.; Soderquist, J. A. J. Org. Chem. 1998, 63, 461-470. doi:10.1021/jo971681s

247.Pantcheva, I.; Nishihara, Y.; Osakada, K. Organometallics 2005, 24, 3815-3817. doi:10.1021/om049050t

248.Zhao, P.; Incarvito, C. D.; Hartwig, J. F. J. Am. Chem. Soc. 2007, 129, 1876-1877. doi:10.1021/ja068587q

249.Deprez, N. R.; Sanford, M. S. J. Am. Chem. Soc. 2009, 131, 11234-11241. doi:10.1021/ja904116k

250. Cotton, F. A.; Koshevoy, I. O.; Lahuerta, P.; Murillo, C. A.; Sanaú, M.; Ubeda, M. A.; Zhao, Q. J. Am. Chem. Soc. 2006, 128, 13674-13675. doi:10.1021/ja0656595

251.Powers, D. C.; Ritter, T. Palladium(III) in Synthesis and Catalysis. In Higher Oxidation State Organopalladium and Platinum Chemistry; Canty, A. J., Ed.; Topics in Organometallic Chemistry, Vol. 35; Springer: Berlin, Germany, 2011; pp 129-156. doi:10.1007/978-3-642-17429-2_6

252.Powers, D. C.; Xiao, D. Y.; Geibel, M. A. L.; Ritter, T. J. Am. Chem. Soc. 2010, 132, 14530-14536. doi:10.1021/ja1054274 253.Sehnal, P.; Taylor, R. J. K.; Fairlamb, I. J. S. Chem. Rev. 2010, 110, 824-889. doi:10.1021/cr9003242

254. Racowski, J. M.; Dick, A. R.; Sanford, M. S. J. Am. Chem. Soc. 2009, 131, 10974-10983. doi:10.1021/ja9014474

255. Catellani, M.; Motti, E.; Della Ca', N. Acc. Chem. Res. 2008, 41, 1512-1522. doi:10.1021/ar800040u

\section{License and Terms}

This is an Open Access article under the terms of the Creative Commons Attribution License (http://creativecommons.org/licenses/by/2.0), which permits unrestricted use, distribution, and reproduction in any medium, provided the original work is properly cited.

The license is subject to the Beilstein Journal of Organic Chemistry terms and conditions:

(http://www.beilstein-journals.org/bjoc)

The definitive version of this article is the electronic one which can be found at: doi:10.3762/bjoc. 12.99 